Review

\title{
Fungal Naphthalenones; Promising Metabolites for Drug Discovery: Structures, Biosynthesis, Sources, and Pharmacological Potential
}

\author{
Sabrin R. M. Ibrahim ${ }^{1,2, *(D)}$, Sana A. Fadil ${ }^{3}$, Haifa A. Fadil ${ }^{4}$, Bayan A. Eshmawi ${ }^{5}$, Shaimaa G. A. Mohamed ${ }^{6}$ \\ and Gamal A. Mohamed ${ }^{3}$ D
}

check for

updates

Citation: Ibrahim, S.R.M.; Fadil, S.A.; Fadil, H.A.; Eshmawi, B.A.;

Mohamed, S.G.A.; Mohamed, G.A Fungal Naphthalenones; Promising Metabolites for Drug Discovery:

Structures, Biosynthesis, Sources, and Pharmacological Potential. Toxins 2022, 14, 154. https://doi.org/ $10.3390 /$ toxins 14020154

Received: 17 January 2022

Accepted: 16 February 2022

Published: 19 February 2022

Publisher's Note: MDPI stays neutral with regard to jurisdictional claims in published maps and institutional affiliations.

Copyright: (c) 2022 by the authors. Licensee MDPI, Basel, Switzerland. This article is an open access article distributed under the terms and conditions of the Creative Commons Attribution (CC BY) license (https:// creativecommons.org/licenses/by/ $4.0 /)$.
1 Department of Chemistry, Preparatory Year Program, Batterjee Medical College, Jeddah 21442, Saudi Arabia 2 Department of Pharmacognosy, Faculty of Pharmacy, Assiut University, Assiut 71526, Egypt

3 Department of Natural Products and Alternative Medicine, Faculty of Pharmacy, King Abdulaziz University, Jeddah 21589, Saudi Arabia; safadil@kau.edu.sa (S.A.F.); gahussein@kau.edu.sa (G.A.M.)

4 Department of Clinical and Hospital Pharmacy, Faculty of Pharmacy, Taibah University, Almadinah Almunawarah 30078, Saudi Arabia; hfadil@taibahu.edu.sa

5 Department of Pharmaceutics, Faculty of Pharmacy, King Abdulaziz University, Jeddah 21589, Saudi Arabia; beshmawi@kau.edu.sa

6 Faculty of Dentistry, British University, El Sherouk City, Suez Desert Road, Cairo 11837, Egypt; shaimaag1973@gmail.com

* Correspondence: sabrin.ibrahim@bmc.edu.sa; Tel.: +966-58-118-3034

\begin{abstract}
Fungi are well-known for their abundant supply of metabolites with unrivaled structure and promising bioactivities. Naphthalenones are among these fungal metabolites, that are biosynthesized through the 1,8-dihydroxy-naphthalene polyketide pathway. They revealed a wide spectrum of bioactivities, including phytotoxic, neuro-protective, cytotoxic, antiviral, nematocidal, antimycobacterial, antimalarial, antimicrobial, and anti-inflammatory. The current review emphasizes the reported naphthalenone derivatives produced by various fungal species, including their sources, structures, biosynthesis, and bioactivities in the period from 1972 to 2021 . Overall, more than 167 references with 159 metabolites are listed.
\end{abstract}

Keywords: naphthalenones; fungi; polyketides; biosynthesis; phytotoxic; bioactivities

Key Contribution: Naphthalenone derivatives have diverse chemical structures and various bioactivities. They could be utilized as building blocks for the synthesis of various compounds for treating diverse human disorders. However, the in-vivo assessment of their potential activities and mechanistic studies should undoubtedly be the focus of future research.

\section{Introduction}

Fungi are the second-biggest group of organisms after insects [1]. Many fungal species have a wide range of biotechnological and industrial potential [2-7]. They are acknowledged as one of the wealthiest pools of natural metabolites among living organisms due to their unique metabolic system and their capacities to synthesize diverse kinds of metabolites with quite intriguing chemical skeletons [8,9]. These metabolites possess a wide range of applications as agrochemicals, antibiotics, immune-suppressants, anti-parasitic, and anticancer agents [10-20]. Naphtalenones are among the naphthalene derivatives produced by fungi that are strictly related to napthoquinones and involved in the branched pathway of fungal DHN (1,8-dihydroxynaphthalene)-melanin biosynthesis [21,22]. Also, they belong to a group of renowned phytotoxins produced by various crop and forest plants pathogenic fungi [22-24]. Moreover, naphthalenone derivatives possess a great structural diversity not only in the planar structure but also in the absolute configuration. Many reported reviews 
mention naphthalenones only as fungal phytotoxins [22-24]. In fact, they have other interesting bioactivities in addition to their phytotoxic activity such as antiviral, antimicrobial, nematocidal, antimycobacterial, cytotoxic, antimalarial, and inhibitory enzyme activities. To our knowledge, no detailed review about fungal naphthalenone derivatives has been published. Thus, this review aims at giving an overview of reported fungal naphthalenone derivatives, their structures, sources, biosynthesis, and bioactivities in the period from 1972 until 2021 (Supplementary Material Tables S1 and S2). Their fungal source, molecular weights and formulae, hosts, and location of the reported naphthalenone derivatives have been listed in Table S1. It was observed that some errors and overlapping in the compound names have arisen, where there are multiple names for one chemical structure. Therefore, the additional names for compounds have been added in brackets (Table S1). Also, the results of the biological activities of the most active derivatives have been summarized in Table S2. Highlighting the bioactivities of these metabolites may attract attention to the synthesis of new agents by medicinal and synthetic chemists using the known naphthalenones as start materials. Literature searching for the published studies was accomplished through diversified databases: PubMed (MedLine), Web of Science, GoogleScholar, SciFinder, and Scopus, as well as through different publishers; Springer-Link, Wiley, Taylor \& Francis, Bentham, and ACS (American Chemical Society) Publications utilizing keywords (naphthalenone, fungi, biosynthesis, and activities).

\section{Biosynthesis of Naphthalenones}

Naphthalenones have been inferred to be biosynthesized in melanin-forming fungi from DHN (1,8-dihydroxynaphthalene) as precursors via acetogenic pathway (Scheme 1). Therefore, these metabolites have a role in fungal melanin biosynthesis. DHN biosynthesis begins with the pentaketide chain. Subsequently, T4HN (1,3,6,8-tetrahydroxynaphthalene) is produced, which is changed to T3HN (1,3-8-trihydroxy naphthalene) via dehydration and reduction reactions. The reduction of T3HN yields vermelone (14), which is changed to DHN by dehydration reaction [13,23-26]. Zhang et al. reported that the polyketide synthesis was started by respective condensations of five acetate units that give compounds $\mathbf{1}, \mathbf{8}, \mathbf{1 9}$, and 22, and of six acetate units producing compounds 27 and 63 [27] (Scheme 1). Barnes et al. reported that the regiodivergent folding of the hexaketide chain gives rise to various bicyclic cores [21] and various tailoring reactions, particularly the oxido-reductions produce $\mathbf{2}, \mathbf{4 0}, \mathbf{4 5}, \mathbf{6 3}$, and $\mathbf{6 5}$, as well as juglone and DHN (Scheme 1).

Further, naphthalenones are also strictly related to napthoquinones, therefore, several naphthoquinones are linked to the biosynthesis of naphthalenones $[23,24,26]$. Moreover, it was postulated that $\mathbf{1 3 1}$ results from region-isomeric ortho-coupling of DHN and juglone. The C-O-bridged strained ring system may be produced by a reduced intermediate condensation or by an intra-molecular addition reaction, including a quinone-methide precursor [21]. Luo et al. postulated that the biosynthesis for 133 involves a Diels-Alder addition, followed by an $\alpha$-ketol kind of rearrangement [28]. Accordingly, the Diels-Alder reaction of the diene III produced from I and the O-demethyl derivative of II (IV) yields the 6/6/6/6-fused tetracyclic intermediate $\mathbf{V}$, which undergoes an $\alpha$-ketol rearrangement, giving the $6 / 6 / 7 / 6$ tetracyclic intermediate VI. Subsequently, VI undergoes a cyclization between the $\mathrm{C}-3$ carbonyl and $20-\mathrm{OH}$, resulting in an acetal and forming the tetrahydrofuran ring of 133 [28] (Scheme 2). 


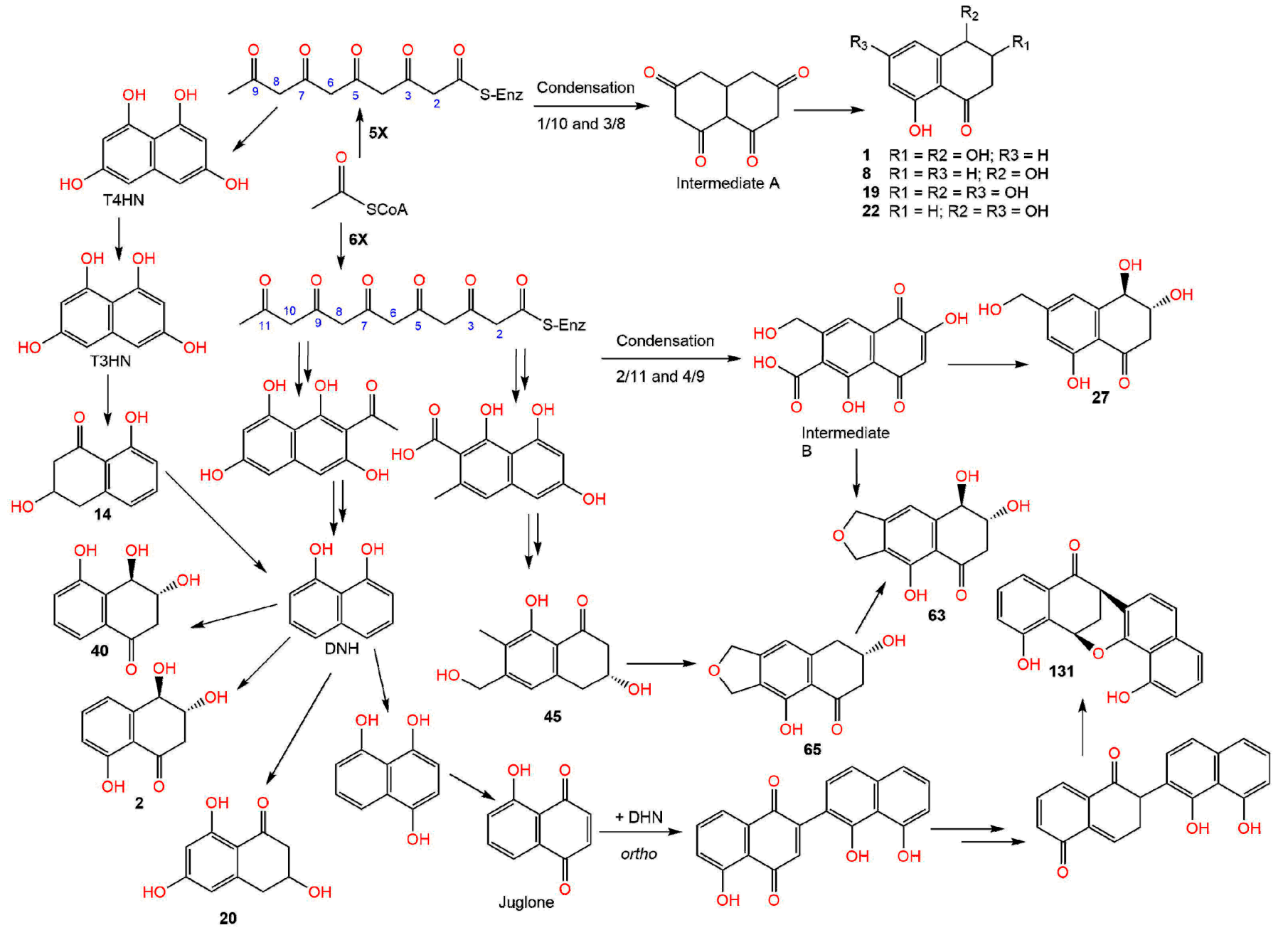

Scheme 1. Biosynthesis of compounds 1, 8, 19, 20, 22, 27, 45, 63, 65, and 131 [21,26,27].
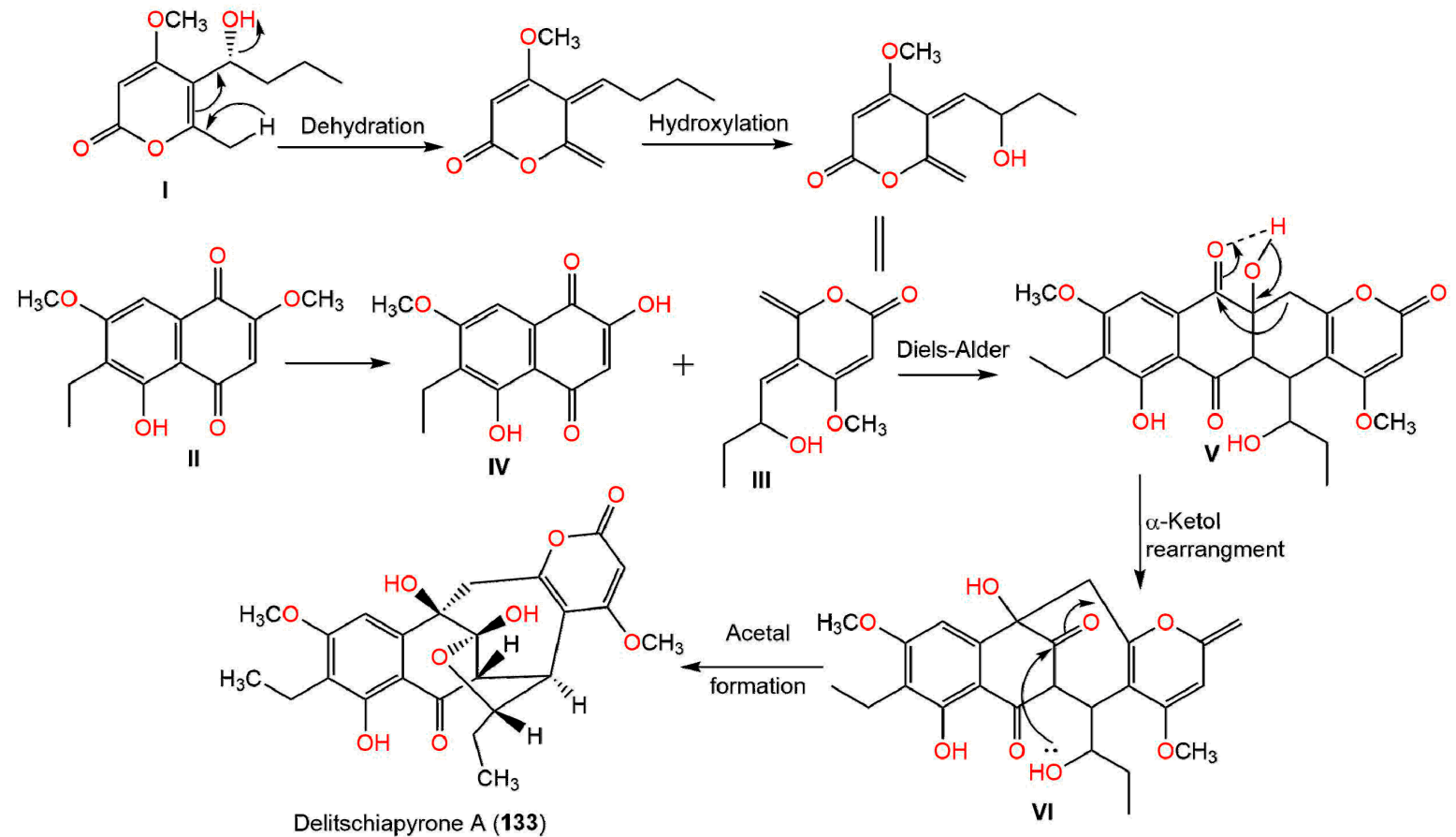

Scheme 2. Biosynthesis of compound 133 [28]. 
Moreover, the possible biosynthetic pathway of $\mathbf{1 4 0}$ was proposed by Li et al., who proposed that the indole unit was derived from tryptophan, however, the naphthalenone unit was derived from propionyl-CoA. The key step in this pathway is the building up of the C-C bond between C-11 and C-4 of the two units [29] (Scheme 3).<smiles>[R16]C(C)CC[C@]1(C)C(=O)C(C(=O)O)C(=O)c2c(O)cccc21</smiles>

Scheme 3. Biosynthesis of compound 140 [29].

\section{Bioactivities of Naphthalenones}

The reported naphthalenones have been investigated for various bioactivities. In this regard, these metabolites have been associated with many types of bioactivities, including phytotoxic, antiviral, antimicrobial, nematocidal, antimycobacterial, cytotoxic, antimalarial, anti-inflammatory, insecticidal, and alpha-glucosidase and IDO inhibitory activities. Herein, these activities have been discussed and results of the most active metabolites have been listed in Table S2.

\subsection{Phytotoxic and Nematocidal Activities}

Weeds represent the most common and severe biotic factors affecting agriculture and are responsible for remarkable agricultural losses. They have negative effects on the crop plants because of the competition for water, nutrients, sunlight, and space. Additionally, they can be a reservoir for certain plant pathogenic microorganisms and/or herbivorous insects [30]. Integrated management strategies are generally applied for controlling weeds by using mechanical methods along with synthetic herbicides [22]. However, the extensive use of synthetic herbicides has toxic effects not only on the target organism but also on animals and humans, in addition to the adverse environmental impacts and promotion of the emergence of herbicide-resistant species. Therefore, research interest has been directed toward identifying new bioherbicides of natural origin [31]. Fungi are known to have the capacity to produce diverse arrays of secondary metabolites that could be beneficial as bioherbicidal agents [22]. Fungal phytotoxic metabolites have a crucial role in developing disease symptoms in host plants. Although they can cause significant damage to crops, naphthalenones can also function as starting material for the development of 
natural herbicides to control the growth and spread of weeds [32]. Interestingly, many of the reported naphthalenones have been found to possess phytotoxic potential. These phytotoxic properties could be utilized for developing simple, rapid, and specific tools to identify plant diseases such as a test kit (e.g., rapid test strip) that can be used directly by farmers in the field. Additionally, they can be used as lead compounds by allowing the synthesis of more phytotoxic compounds on a range of weeds based on their structures for potential application as herbicides. Compound 1 isolated from Pyricularia Oryzae reduced the rice seedlings' growth at high concentrations, however, it slightly stimulated the rice seedlings' growth at a concentration of $100 \mathrm{ppm}$ in $24 \mathrm{~h}$ [33]. Masi et al. reported that the culture filtrate of Pyricularia grisea afforded $\mathbf{2}$ and $\mathbf{9}$ (Figure 1), which were assessed for their phytotoxicity toward buffelgrass (Cenchrus ciliaris) using radicle elongation and buffelgrass coleoptile bioassay. They significantly delayed the seed germination relative to the control, whereas $\mathbf{2}$ also apparently reduced the germination percentage [34].

Moreover, 2 inhibited Lepidium sativum and Setaria italica germinated seed growth $\left(\mathrm{IC}_{50}\right.$ 50 and $100 \mu \mathrm{g} /$ disc, respectively) [35]. Further, the cup fungus, Urnula craterium yielded 4 and 9 that had no in-vitro activity toward the aspen pathogens: Ophiostoma piliferum, $O$. crassivaginatum, and Populus tremulae (conc. up to $100 \mu \mathrm{g} / \mathrm{mL}$ ) [36]. Also, it was found that 9 (conc.1-10 ppm) stimulated the rice seedlings' root elongation by $\approx 30 \%$, whereas 8 did not have any stimulating effect. On the other hand, both 8 and 9 prohibited (Conc. $50 \mathrm{ppm}$ ) the rice seedlings' shoot and root growth with readily observable chlorosis (white spots) on leaves [33,37].

Additionally, 1, 9, and 21 were separated from the liquid culture of Tubakia dryina, the causative agent of Quercus rubra (red oak) leaf spot. In the detached leaf assay, these metabolites caused large lesions on the red oak leaves that developed along the veins within $24 \mathrm{~h}$, very similar to those resulting from T. dryina infection. On the other hand, they had a moderate phytotoxic effect on white oak, prickly sida, and sorghum [38].<smiles></smiles>

\begin{tabular}{|c|c|c|c|c|}
\hline & $\mathbf{R}^{1}$ & $\mathbf{R}^{2}$ & $\mathbf{R}^{3}$ & $\mathbf{R}^{4}$ \\
\hline $1=$ & $\mathrm{H}$ & $-\mathrm{OH}$ & $\ldots$ & $\mathrm{OH}$ \\
\hline $2=$ & $\mathrm{H}$ & $\cdots$ & $-\mathrm{OH}$ & $\mathrm{OH}$ \\
\hline $3=$ & H & $-\mathrm{OH}$ & $-\mathrm{OH}$ & $\mathrm{OH}$ \\
\hline $4=-$ & $-\mathrm{OH}$ & $\mathrm{H}$ & $\mathrm{-..m+ \textrm {O }}$ & $\mathrm{OH}$ \\
\hline $5=$ & "."'OH & $\mathrm{H}$ & $-\mathrm{OH}$ & $\mathrm{OH}$ \\
\hline $6=\cdots$ & "wa'OH & $\mathrm{H}$ & $\cdots \mathrm{moH}$ & $\mathrm{OH}$ \\
\hline $7=-$ & $-\mathrm{OH}$ & $\mathrm{H}$ & $-\mathrm{OH}$ & $\mathrm{OH}$ \\
\hline $8=$ & $\mathrm{H}$ & $\mathrm{H}$ & $-\mathrm{OH}$ & $\mathrm{OH}$ \\
\hline $9=$ & $\mathrm{H}$ & $\mathrm{H}$ & $-\mathrm{m}=\mathrm{m} \mathrm{OH}$ & $\mathrm{OH}$ \\
\hline $10=$ & $\mathrm{H}$ & $\mathrm{H}$ & $\cdots \cdots+\mathrm{OAC}$ & $\mathrm{OH}$ \\
\hline $11=$ & $\mathrm{H}$ & H & $\cdots$ & $\mathrm{OCH}_{3}$ \\
\hline $12=$ & $\mathrm{H}$ & $\mathrm{H}$ & $-\mathrm{OH}$ & $\mathrm{OH}$ \\
\hline $13=$ & $\mathrm{H}$ & $\ldots$ &. & $\mathrm{OH}$ \\
\hline $4=$ & $\mathrm{H}$ & $-\mathrm{OH}$ & $\mathrm{H}$ & $\mathrm{OH}$ \\
\hline $5=$ & $\mathrm{H}$ & $\mathrm{H}$ & - Or & $\mathrm{H}$ \\
\hline
\end{tabular}<smiles>[R]c1cc([R])c2c(c1)C([R])C([R])C([R])C2=O</smiles>

\begin{tabular}{|c|c|c|c|c|}
\hline $\mathbf{R}^{1}$ & $\mathbf{R}^{2}$ & $\mathbf{R}^{3}$ & $R^{4}$ & $\mathbf{R}$ \\
\hline $6=$ & $\mathrm{H}$ & $-\mathrm{OH}$ & $\mathrm{OH}$ & $\mathrm{H}$ \\
\hline $7=$ & ...m- & $\mathrm{H}$ & $\mathrm{OH}$ & $\mathrm{OH}$ \\
\hline $8=$ &..$\cdots \mathrm{moH}$ & $\mathrm{H}$ & $\mathrm{OCH}_{3}$ & $\mathrm{OH}$ \\
\hline $\mathrm{H}$ & $-\mathrm{OH}$ & $-\mathrm{OH}$ & $\mathrm{OH}$ & $\mathrm{Ol}$ \\
\hline $\mathrm{H}$ & $\sim \mathrm{OH}$ & $\mathrm{H}$ & $\mathrm{OH}$ & $\mathrm{OH}$ \\
\hline $\mathrm{H}$ & $\mathrm{H}$ & $\cdots$ & $\mathrm{OH}$ & $\mathrm{OH}$ \\
\hline $\mathrm{H}$ & $\mathrm{H}$ & $-\mathrm{OH}$ & $\mathrm{OH}$ & $\mathrm{OH}$ \\
\hline$=\ldots \ldots m \mathrm{OH}$ & $\mathrm{H}$ & $\mathrm{H}$ & $\mathrm{OH}$ & $\mathrm{H}$ \\
\hline $\mathrm{H}$ & $-\mathrm{OH}$ & $-\mathrm{OH}$ & $\mathrm{OH}$ & $\mathrm{H}$ \\
\hline $\mathrm{H}$ & $\mathrm{H}$ & $-\mathrm{OH}$ & $\mathrm{OH}$ & $\mathrm{OH}$ \\
\hline $\mathrm{H}$ & $-\mathrm{OH}$ & $\cdots$ & $\mathrm{OH}$ & $\mathrm{OH}$ \\
\hline $\mathrm{H}$ & $\cdots$ & $-\mathrm{OH}$ & $\mathrm{CH}_{2} \mathrm{OH}$ & $\mathrm{OH}$ \\
\hline $8=$ & $-\mathrm{OH}$ & $-\mathrm{OH}$ & $\mathrm{OH}$ & $\mathrm{OH}$ \\
\hline $\mathrm{H}$ & $-\mathrm{OH}$ & $-\mathrm{OH}$ & $\mathrm{OCH}_{3}$ & $\mathrm{OH}$ \\
\hline $\mathrm{H}$ & $-\mathrm{OH}$ & $\cdots$ & $\mathrm{OCH}_{3}$ & $\mathrm{OH}$ \\
\hline $\mathrm{H}$ & $\cdots$ & $-\mathrm{OH}$ & $\mathrm{OCH}_{3}$ & $\mathrm{OH}$ \\
\hline $\mathrm{H}$ & $\cdots$ & $-\mathrm{OH}$ & $\mathrm{OH}$ & $\mathrm{OH}$ \\
\hline $\mathrm{OH}$ & $\mathrm{H}$ & $-\mathrm{OH}$ & $\mathrm{OH}$ & $\mathrm{OH}$ \\
\hline$U$ & $\mathrm{CH}_{2}$ & $-\mathrm{Or}$ & $\mathrm{OCH}_{3}$ & $\mathrm{OH}$ \\
\hline
\end{tabular}

Figure 1. Structures of compounds 1-34. 
The pathogenic fungus, Ceratocystis fimbriata f. sp. platani that caused canker stain in the plane tree (Platanus acerifolia) produced 4 and 5 , which produced large necrotic lesions in the plane tree tissues at a concentration of $1.0 \mathrm{mg} / \mathrm{mL}$, whereas 17 possessed significant necrosis only after 7 days, whereas 19 and 28 exhibited less activity after $48 \mathrm{~h}$ [39]. Compound 7 was separated from Mycosphaerella fijiensis IMI 105378, the causative agent of Black Sigatoka disease in plantains and bananas. It induced necrotic lesions (Conc. $5 \mu \mathrm{g} / 5 \mu \mathrm{L}$ ) in $<12 \mathrm{~h}$ on the sensitive cultivars of bananas in the leaf-puncture bioassay [40]. Ceratocustis fimbriata that is accountable for the canker disease of the coffee tree yielded $\mathbf{1 4}$ and 17 that exhibited no remarkable toxic effect on coffee trees (conc. $1 \times 10^{-3} \mathrm{M}$ ) [41] Furthermore, $\mathbf{1 2}$ and $\mathbf{1 7}$ were separated from Phaeoacremonium aleophilum associated with the esca of grapevine. Compound 12 (Conc. $0.1 \mathrm{mg} / \mathrm{mL}$ ) produced large, coalescent necrotic, and chlorotic spots then withering and distortion of the lamina, however, 17 (Conc. $0.05 \mathrm{mg} / \mathrm{mL}$ ) produced light green to chlorotic, rounded to irregular, inter-veinal, or marginal spots on the grapevine detached leaves. Thus, they caused similar symptoms to those shown by the vines leaves with brown wood-streaking that is associated with wood infection by P. chlamydosporum and P. aleophilum [42]. Moreover, 17 separated from Raffaelea quercivora, which caused the Japanese oak wilt disease, inhibited (Conc. $100 \mu \mathrm{g} / \mathrm{mL}$ ) the lettuce seedlings' root growth to $54.8 \%$ of the negative control [43]. On the other hand, 22 slightly promoted the second leaves growth (Conc. 500 ppm) and 33 possessed no noticeable activity on the growth of rice seedlings [33,37]. Whilst 48 had a weak phytotoxic activity toward Lepidium sativum ( $\mathrm{IC}_{50} 100 \mu \mathrm{g} /$ disk) [44]. The new naphthalenone; botrytone (42), along with the formerly separated 3, 4, and 8 were purified from the culture filtrate of Botrytis fabae associated with Vicia faba (fava bean). Compound 8 displayed the highest phytotoxicity together with 3 and 4 on the Vicia faba leaves, however, 42 had moderate potential (Conc. $1 \mathrm{mg} / \mathrm{mL}$ ) [44]. Neofusicoccum australe strain BL24 (haplotype H1) produced 31 and 53 (Figure 2).

They were assessed for phytotoxic activity on the leaves of holm oak, cork oak, and grapevine leaves utilizing leaf-puncture assay (Conc. 0.125, 0.25, 0.5, and $1 \mathrm{mg} / \mathrm{mL}$ ). Compound 53 was much less toxic even at the highest concentration. It caused necrotic lesions on the leaves of cork oak, holm oak, and grapevine (area lesions $4.8,3.3$, and $11.9 \mathrm{~mm}^{2}$, respectively). On the other hand, 31 did not possess any phytotoxic effect [45]. Neofusicoccum paroum is one of the most virulent botryosphaeriaceous species that affect the grapevine. Investigation of its extract yielded 9, 40,53, and 94 that were found to be phytotoxic on grapevine leaves in the leaf puncture assay, with 53 having the greatest potential [46]. Masi et al. purified lentiquinones B (115) and C (116) from the culture filtrate of Ascochyta lentis separated from the diseased lentil (Lens culinaris). Both compounds had the same structure but differed in C-2-OH group configuration, showing $\alpha$ - and $\beta$-configuration, respectively. They featured three six-membered rings skeleton, involving trihydroxy-cyclohexene and hemi-quinone rings. Their absolute configuration was assigned as $2 \mathrm{R}, 3 \mathrm{~S}, 4 \mathrm{~S}, 4 \mathrm{aS}, 10 \mathrm{R}$ and 2S,3S,4S,4aS,10R, respectively using X-ray, ECD (electronic circular dichroism), and TDDFT (time-dependent DFT) calculations. They showed strong phytotoxicity toward Lupinus albus and Chenopodium album in the leaf puncture assay [47]. Compound 132 biosynthesized by Guignardia laricina inhibited the growth of lettuce seedling roots by 71.5, 16.2, and 7.0\% at concentrations of 100,250, and 50 ppm, respectively in the lettuce seedling bioassay [48].

Plant-parasitic nematodes are plant pathogens that can cause significant reductions in agricultural yields resulting in substantial annual economic losses to growers [49]. Chemical nematocidal agents such as organophosphorus and carbamate are used for controlling these parasitic nematodes, however, their long-term use can result in increased nematode resistance, as well as deleterious effects on human health [50]. Recently, research has emphasized the discovery of nematocidal agents from natural sources including the nematocidal potential of naphthalenone derivatives. Therefore, some studies reported the nematocidal potential of naphthalenone derivatives. 


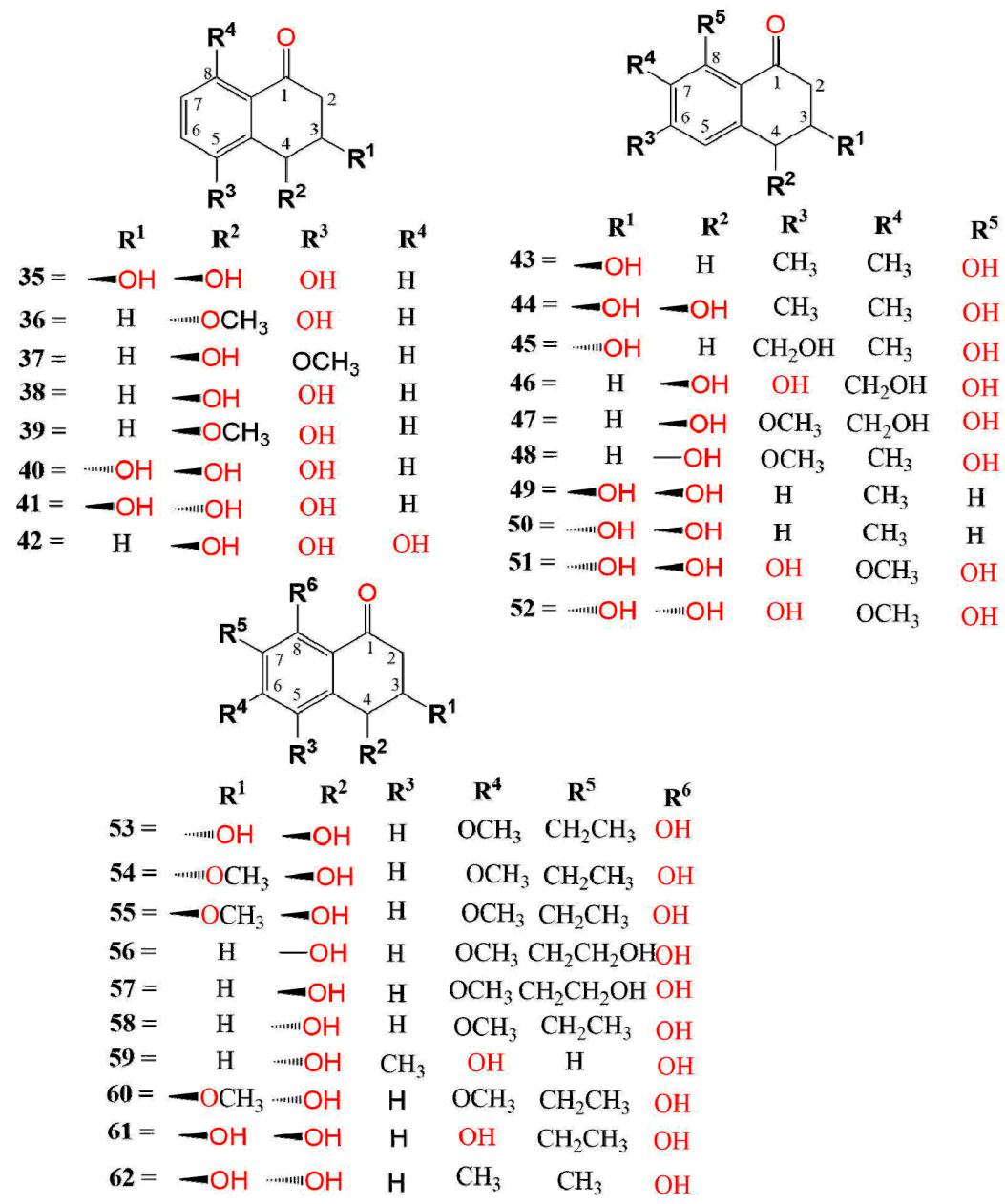

Figure 2. Structures of compounds 35-62.

Compounds 9 and 22 isolated from an unidentified freshwater fungus YMF 1.01029 exhibited weak nematocidal potential toward the nematode Bursaphelenchus xylophilus [51]. The four naphthalenones; 8, 9, 19, and 22 separated from the cultural extract of Caryospora callicarpa were assessed in-vitro for antinematodal activity toward Bursaphelenchus xylophilus (fungal-feeding and plant-parasitic nematode) in the nematotoxin bioassay. They showed noticeable nematocidal potential, which was significantly enhanced with the exposure times length at the same concentration ( $\mathrm{LC}_{50} \mathrm{~s}$ (lethal concentration 50 ) 209.7, 229.6, 220.3, and $206.1 \mathrm{mg} / \mathrm{L}$, respectively at $36 \mathrm{~h}$ exposure). Their mode of action was suggested to be systemic, instead of contact poisons or antifeedants [52].

\subsection{Antimicrobial, Antimycobacterial, and Anti-Plasmodial Activities}

Infectious diseases are a worldwide health problem. Multidrug-resistant (MDR) pathogens remarkably increase morbidity and mortality rates [53]. The continuous emergence of MDR pathogens drastically reduced the efficacy of antibiotics resulting in a growing rate of therapeutic failure [54]. Accordingly, new and effective antimicrobial agents to address microbial infections are needed.

Inácio et al. purified $\mathbf{3}$ and $\mathbf{8}$ from Cryptocarya Mandioccana healthy leaves associated with Colletotrichum gloeosporioides by RP-HPLC (reversed phase-high performance liquid chromatography) and evaluated their antifungal activity by direct bioautography on TLC (thin layer chromatography) plate, which includes spraying the fungal suspensions on the developed TLC plates utilizing solvents of different polarities for detecting the antifungal potential of these compounds [55]. The effectiveness was indicated by white spots against a red-purple background on the TLC plates after spraying with tetrazolium violet [56]. It 
was found that the required detection limit of these compounds for inhibiting the growth of the phytopathogenic fungi: Cladosporium sphaerospermum and C. cladosporioides was $5.0 \mathrm{mg}$, compared with nystatin [55]. On the other hand, 2 and 17 obtained from Lachnellula sp. cultures had no antimicrobial potential (Conc. $100 \mu \mathrm{g} / \mathrm{mL}$ ) in the serial broth dilution assay toward A. calcoaceticus, M. luteus, M. miehei, and P. variotii [35]. Findlay and Kwan stated that 9 and 17 purified from Scytalidium FY had significant antifungal activity [57]. On the other side, 9 had weak activity against B. subtilis ( $\left.\mathrm{IC}_{50} 100 \mu \mathrm{g} / \mathrm{mL}\right)$, compared with chloramphenicol ( $\mathrm{IC}_{50} 3.13 \mu \mathrm{g} / \mathrm{mL}$ ) in the colorimetric assay [58] and no activity toward $M$. smegmatis, S. aureus, S. cerevisiae, C. neoformans, C. albicans, E. coli, A. niger, and Micrococcus luteus [59]. Lu et al. separated 10 from Cytospora sp. isolated from Ilex canariensis that showed antibacterial activity (IZD (inhibition zone diameter) $15.0 \mathrm{~mm}$ ) toward Bacillus megaterium in the agar diffusion assay, compared with penicillin (IZD $28.0 \mathrm{~mm}$ ) [60].

Pittayakhajonwut et al. purified 9, 13, 14, 22, 28, and 31 from Phaeosphaeria sp. Compounds 13, 22, and 31 possessed significant anti-mycobacterial activity (MICs (minimum inhibitory concentrations) $12.5,12.5$, and $25.0 \mu \mathrm{g} / \mathrm{mL}$, respectively), whereas 9 and 14 had moderate effectiveness (MIC $50.0 \mu \mathrm{g} / \mathrm{mL}$ ), compared to isoniazid and kanamycin (MICs 0.05 and $2.5 \mu \mathrm{g} / \mathrm{mL}$, respectively) using the micro-plate Alamar blue assay (MABA) [61]. On the other side, 2 had no noticeable antifungal effect toward C. albicans (MIC > $128 \mu \mathrm{g} / \mathrm{mL}$ ) in the XTT (cell proliferation kit II) assay [62].

The new derivative, 25, and the formerly reported 1 and 3 were separated from the endolichenic fungus, Xylariaceae sp. CR1546C obtained from Costa Rican lichen Sticta fuliginosa. The C-4 R-configuration of $\mathbf{2 5}$ was deduced based on the Mosher method and the opposite optical rotation sign to that of similar structural metabolite-21. These metabolites exhibited weak antifungal potential toward C. albicans with MFCs (minimum fungicidal concentrations) between 100 and $150 \mu \mathrm{g} / \mathrm{mL}$ and $\mathrm{IC}_{50}$ from 60 to $100 \mu \mathrm{g} / \mathrm{mL}$, compared to amphotericin $\mathrm{B}\left(\mathrm{IC}_{50} 1.3 \mu \mathrm{g} / \mathrm{mL}\right)$ using broth-dilution technique [63].

The endophytic fungus Daldinia eschscholtzii associated with the mangrove plant Bruguiera gymnorrhiza yielded a new metabolite; (3S)-3,8-dihydroxy-6,7-dimethyl-a-tetralone (43), along with 9. The C-3 absolute configuration of 43 was determined as $S$ based on the CD spectrum. These compounds had weak antimicrobial potential toward S. aureus, M. gypseum, and MRSA (MICs $200 \mathrm{mg} / \mathrm{mL}$ ) [64]. Cladosporium sp. JJM22 isolated from Ceriops tagal stem bark also yielded 43 that showed a broad spectrum of antibacterial potential versus $V$. parahemolyticus, S. aureus, E. coli, V. alginolyticus, B. cereus, and MRSA at a concentration of $20 \mu \mathrm{M}$ [65].

Compounds 44 and 64, two new dihydronaphthalenones were purified from Nodulisporium sp. isolated from Antidesma ghaesembilla fresh twigs (Figure 3). Compound 64 had C6/C7 fused furan ring. The $3 R, 4 S$ and $7 R, 8 S$ stereo-configurations of these metabolites were deduced based on the coupling constants, NOE (nuclear overhauser effect), optical rotations, and X-ray analysis. Compound 64 exhibited anti-mycobacterial potential ( $\mathrm{IC}_{50}$ $3.125 \mu \mathrm{g} / \mathrm{mL}$ ) toward M. tuberculosis H37Ra and antimalarial effectiveness versus $P$. falciparum $\mathrm{K} 1$ ( $\mathrm{IC}_{50} 11.3 \mu \mathrm{g} / \mathrm{mL}$ ) using the GFPMA (green fluorescent protein micro-plate assay) and micro-culture radioisotope technique, respectively, however, 44 was inactive [66]. Moreover, 48 possessed weak antimicrobial activity (MIC $100 \mu \mathrm{g} / \mathrm{mL}$ ) toward M. luteus, E. dissolvens, M. miehei, P. variotii, and P. notatum in the serial broth dilution assay [44].

The new derivative, 61, separated from the aquatic fungus Delitschia corticola was reported to have moderate antifungal potential toward Sclerotium sp. YMF-1.01993, Alternaria sp. YMF-1.01991, and Fusarium sp. YMF-1.01996 (IZDs 8.0, 7.0, and $7.0 \mathrm{~mm}$, respectively), compared to ciclopirox (IZDs 26.0, 19.0, and $20.0 \mathrm{~mm}$, respectively), however, it had moderate antibacterial effectiveness toward B. cereus YMF-3.19 and B. laterosporus YMF-3.08 (IZDs 12.0 and $10.0 \mathrm{~mm}$, respectively), compared to ampicillin sodium (IZDs 35.0 and 30.0 , respectively) and stronger activity (IZD $20.0 \mathrm{~mm}$ ) more than ampicillin sodium (IZD $18.0 \mathrm{~mm}$ ) toward S. aureus YMF-3.17 [67]. 


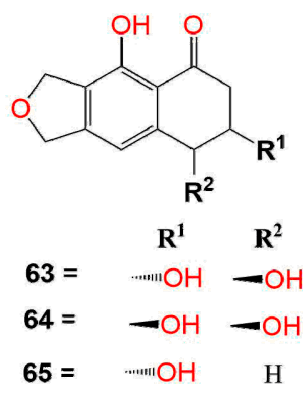<smiles>C[C@@H](O)C[C@]1(O)CC(=O)c2c(O)cc(O)cc2C1</smiles><smiles>CC(=O)CC1(O)CC(=O)c2c(O)cc(O)cc2C1</smiles><smiles>CCC(C)/C=C(\C)C(=O)CC1(O)CC(=O)c2c(O)cc(O)cc2C1</smiles><smiles>C[C@@H](O)CC(=O)C[C@]1(O)CC(=O)c2c(O)cc(O)cc2C1</smiles><smiles>[R]O[C@H]1c2cc(OC)cc(O)c2C(=O)C2COC([R])(C)C[C@H]2[C@H]1O</smiles><smiles>[3H][Te]OC</smiles><smiles>[Z6]c1cc(O)c2c(c1)[C@H](O)[C@H](CC(C)=O)CC2=O</smiles><smiles>COc1cc(O)c2c(c1)[C@H](O)[C@H](CO)CC2=O</smiles><smiles>COc1cc(O)c2c(c1)[C@H](O)[C@H](CC(C)=O)CC2=O</smiles><smiles>COc1cc(O)c2c(c1)[C@H]1OC(C)(C)OC[C@H]1CC2=O</smiles>

Figure 3. Structures of compounds 63-76.

Compounds 66, 67, and 69 had no anti-malarial effectiveness toward $P$. falciparum K1 [68]. Moreover, they showed no anti-mycobacterial activity versus $M$. tuberculosis H37Ra and no antifungal potential toward Magnaporthe grisea TH16 [68]. Liu et al. isolated 68 from the marine filamentous fungus, Keissleriella sp. Y4108, which possessed growth inhibitory activity toward the human fungal pathogens: Tricophyton rubrum, C. albicans, and A. niger (MICs 20, 40, and $80 \mu \mathrm{g} / \mathrm{mL}$, respectively), in comparison to ketoconazole (MICs 10, 1, and $30 \mu \mathrm{g} / \mathrm{mL}$, respectively) in the broth micro-dilution method [69]. Shushni et al. stated that balticols A-F (74, 75, 78, and 80-82) (Conc. $200 \mu \mathrm{g} /$ disc) exhibited no remarkable antimicrobial activity toward S. aureus, E. coli, and C. maltosa in the agar-diffusion assay [70].

The five metabolites, $\mathbf{8 3 - 8 7}$ biosynthesized by the sea fan-derived Fusarium spp. PSUF135 and PSU-F14 showed weak antibacterial potential versus $S$. aureus and MRSA in the colorimetric broth micro-dilution test [71] (Figure 4).

Furthermore, 85 exhibited antimalarial potential versus $P$. falciparum K1-MDR strain $\left(\mathrm{IC}_{50} 7.94 \mu \mathrm{g} / \mathrm{mL}\right)$, in comparison to dihydroartimisinin $\left(\mathrm{IC}_{50} 0.0012 \mu \mathrm{g} / \mathrm{mL}\right.$ ) in the microculture radioisotope technique and antimycobacterial capacity toward $M$. tuberculosis H37Ra (MIC $12.50 \mu \mathrm{M}$ ) in the green fluorescent protein (GFP)-based fluorescent assay, while 84 showed moderate effect (MIC $25.0 \mu \mathrm{g} / \mathrm{mL}$ ) toward M. tuberculosis H37Ra, compared to kanamycin, rifampicin, and isoniazid (MICs 1.25, 0.047, and $0.25 \mu \mathrm{g} / \mathrm{mL}$, respectively) [71,72].

Perenniporides A-D (90-93), new derivatives isolated from the solid culture of Perenniporia sp. inhabiting the larva of Euops chinesis were characterized by NMR, X-ray, and ECDcalculations. Their configurations were 4R,12R (for 90 and 91), 3R,4R,12R (for 92), and $3 S, 4 R, 12 R$ (for 93). Compound 90 was characterized by the presence of a $\gamma$-lactone ring that was spirally linked to $\mathrm{C}-4$ of the naphthalen- $1(4 \mathrm{H})$-one moiety and represented the first natural naphthalenone, having a $3^{\prime}, 4^{\prime}$-dihydro-2' $\mathrm{H}, 3 \mathrm{H}$-spiro[furan-2,1'-naphthalen]-5(4H)one skeleton. However, 91 possessed a C-13 methyl ester instead of the $\gamma$-lactone ring in 90. Both 92 and 93 had fused THF (tetrahydrofuran) ring and $\delta$-lactone ring, respectively, at C-3/C-4 of the 3,4-dihydronaphthalen-1(2H)-one moiety. They represented the first 
natural metabolites with 1,2,3a,4-tetrahydronaphtho[2,1-b]furan-5(9bH)-one and 4a,5,6,10btetrahydro- $1 H$-benzo[f]chromen-3(2H)-one moiety, respectively. Compound 90 exhibited significant antifungal activity toward a five-plant pathogen panel, including F. moniliforme, V. alboatrum, G. zeae, F. oxysporum, and A. longipes using microplate assay (MIC from 10 to $20 \mu \mathrm{g} / \mathrm{mL}$ ), compared to methyl 2-benzimidazolecarbamate that had antifungal potential against all the tested fungi except for $A$. longipes (MICs 0.63 to $2.5 \mu \mathrm{g} / \mathrm{mL}$ ), whereas 91-93 did not have any noticeable activity (Conc. $20 \mu \mathrm{g} / \mathrm{mL}$ ) [73].<smiles>[R]O[C@H]1c2cc(OC)cc(O)c2C(=O)C[C@@]1([R])CO</smiles>

$$
\begin{array}{rc}
77= & \mathrm{H} \\
\mathbf{7 8}= & \ldots+\cdots+\mathrm{OH} \\
\mathbf{7 9}= & -\mathrm{OH}
\end{array}
$$<smiles>COc1cc(O)c2c(c1O)[C@H](O)[C@H](CC(C)=O)[C@@H](CO)C2=O</smiles><smiles>COc1cc(O)c2c(c1)[C@@H]1OC(C)(OC)C[C@@]1(O)CC2=O</smiles><smiles>[R]C1c2c(O)c(OC)cc(O)c2C(=O)[C@]2(C)[C@@H]1C[C@](C)(O)[C@@H](O)[C@@H]2[R]</smiles><smiles>CCc1c(OC)cc2c(c1O)C(=O)C=C(OC)[C@]21C[C@@H](O)C(=O)O1</smiles><smiles>CCc1c(OC)cc2c(c1O)C(=O)C[C@]1(OC)OC(=O)[C@H](O)C[C@@]21O</smiles><smiles>[R]C1CC(=O)c2c(O)c(C)c3cc(C)oc3c2[C@H]1O</smiles><smiles></smiles>

$88=\quad H$

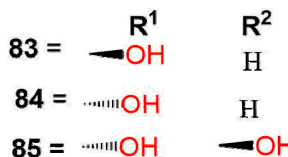<smiles>COc1cc(O)c2c(c1O)[C@H](O)[C@@H]1C[C@](C)(O)[C@@H](O)C[C@H]1C2=O</smiles><smiles>CCc1c(OC)cc2c(c1O)C(=O)C=C(OC)[C@@]2(O)C[C@@H](O)C(=O)OC</smiles><smiles>CCc1c(OC)cc2c(c1O)C(=O)C[C@]1(OC)O[C@@H](C(=O)OC)C[C@@]21O</smiles>

Figure 4. Structures of compounds 77-93.

Also, 53 and 94-96 (Conc. $50 \mu \mathrm{g} / \mathrm{mL}$ ) had no antimicrobial influence versus E. coli, B. subtilis, S. aureus, B. pumilus, C. albicans, and A. niger in the micro-plate assay [74] (Figure 5). Also, compounds 9, 40, 53, and 94 isolated from Neofusicoccum parvum associated with declining grapevines did not show in-vitro antifungal potential versus the plant pathogens; L. mediterranea, D. seriata, N. vitifusiforme, and P. citrophthora [46]. Orchid-associated Daldinia eschscholtzii produced new derivatives: $45,63,65$, and 131, along with the formerly reported 2 and 40. Compound 131 featured an uncommon oxane-connected binaphthyl ring system that revealed the possible biosynthesis of diverse binaphthyls from ring rearrangements and fusions. Compounds 2, 63, 65, and 131 had moderate antimicrobial potential in the agar diffusion assay toward B. subtilis, MRSA, VRE, and P. notatum, with $\mathbf{1 3 1}$ showing the broadest and highest activity [21]. 
<smiles>COc1cc2c(c(O)c1C(C)OC)C(=O)C[C@@H](O)[C@H]2O</smiles><smiles></smiles>

$\mathbf{9 7}=\mathrm{OCH}_{3}$

$98=\mathrm{OH}$<smiles>COc1cc2c(c(O)c1CCO)C(=O)CC[C@@H]2O</smiles><smiles>COc1cc2c(c(O)c1[C@@H](C)O)C(=O)CC[C@H]2O</smiles><smiles>COc1cc2c(c(O)c1C(C)O)C(=O)CC[C@H]2O</smiles>

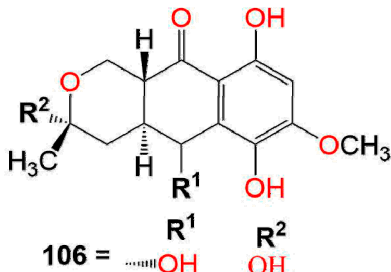<smiles>COc1cc(O)c2c(c1O)[C@H](O)[C@H](CC(C)=O)CC2=O</smiles><smiles>COc1cc(O)c2c(c1O)C(O)C1CC(C)(O)OCC1C2=O</smiles>

$107=\ldots \cdots+\cdots \mathrm{OH} \quad \mathrm{OCH}_{3}$

$108=-\mathrm{OH} \quad \mathrm{OH}$

$109=-\mathrm{OH} \quad \mathrm{OCH}_{3}$

$110=-\mathrm{OCH}_{3} \quad \mathrm{OCH}_{3}$

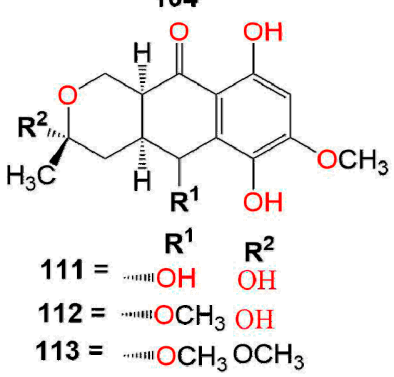<smiles>COc1cc(O)c2c(c1O)[C@H](O)[C@H]1C[C@](C)(O)OC[C@H]1C2=O</smiles><smiles>C1CCCC1</smiles><smiles></smiles>

Figure 5. Structures of compounds 94-116.

A study by Kornsakulkarn et al. reported the separation of the new dihydronaphthalenone derivatives: 98, 99, 104, 106, 107, 111, and 112 and the known 114 from Fusarium sp. BCC14842. Their configuration was assigned using NOESY (nuclear overhauser effect spectroscopy), coupling constants, X-ray, CD (circular dichroism), and modified Mosher method. Only, 99 and 107 showed weak antimycobacterial potential toward M. tuberculosis H37Ra (MIC 25.0 and $50.0 \mu \mathrm{g} / \mathrm{mL}$, respectively), compared to isoniazid (MIC $0.03 \mu \mathrm{g} / \mathrm{mL}$ ) in the GFPMA assay. Moreover, none of them had antifungal activity toward C. albicans $\left(\mathrm{IC}_{50}>50 \mu \mathrm{g} / \mathrm{mL}\right)$ [75]. In the disc diffusion assay, $\mathbf{1 1 5}$ and $\mathbf{1 1 6}$ had antibacterial effectiveness versus B. subtilis (IZD 12.0 and $14.0 \mathrm{~mm}$, respectively) and no activity versus E. coli [47]. Variabilone (134), with a new dihydrofurano-2(1H)-naphthalenone skeleton was purified from Paraconiothyrium variabile obtained from Cephalotaxus harringtonia (yew tree) (Figure 6). Its C-11 R-configuration was determined by SRCD (synchrotron radiation circular dichroism). It is noteworthy that $\mathbf{1 3 4}$ had a significant antibacterial activity versus $B$. subtilis ( IC $_{50}$ $2.13 \mu \mathrm{g} / \mathrm{mL})$, compared to kanamycin $\left(\mathrm{IC}_{50} 0.36 \mu \mathrm{g} / \mathrm{mL}\right)$ in the micro-dilution resazurin assay [76]. Cladosporone A (157), a new dimeric napthalenone linked via C-C bridge was yielded by Cladosporium sp. KcFL6 harboring Kandelia candel, together with 145, 147, and 148. They had no antimicrobial effectiveness versus $A$. baumannii, $S$. aureus, E. faecalis, $A$. hydrophila, E. coli, K. pneumonia, Fusarium sp., F. oxysporum f. sp. cucumeris, F. oxysporum f. sp. niveum, A. niger, and $R$. solani in the disc diffusion assay [77]. 


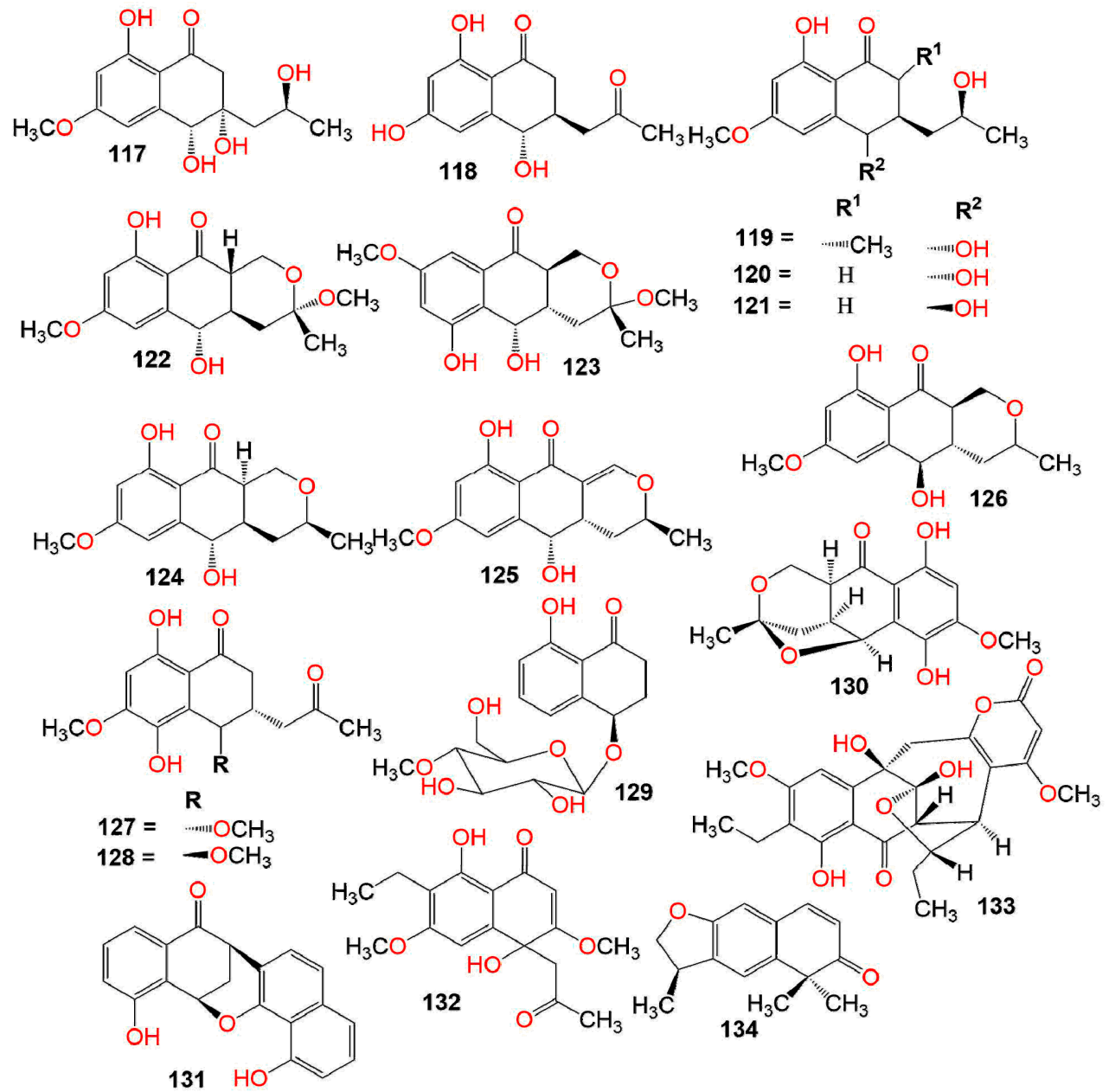

Figure 6. Structures of compounds 117-134.

Moreover, the antimicrobial potential of 147, 150, and 152-155 was assessed versus E. coli, A. hydrophila, S. aureus, E. tarda, P. aeruginosa, M. luteus, V. alginolyticus, V. parahemolyticus, V. harveyi, A. brassicae, F. oxysporum, C. gloeosporioides, G. graminis, and P. piricolav using the micro-plate assay. Compounds 147, 150, and 152-155 showed inhibitory potential toward V. harveyi, M. luteus, and E. coli (MICs 4-128 $\mu \mathrm{g} / \mathrm{mL}$ ) [78]. Further, 147 and 149 demonstrated antibacterial capacity versus S. aureus (MICs 6.25 and $1.56 \mu \mathrm{g} / \mathrm{mL}$, respectively), comparing to ciprofloxacin (MIC $0.39 \mu \mathrm{g} / \mathrm{mL}$ ) [79]. Cladosporium sp. KFD33 separated from blood cockle yielded cladosporol I (154) and altertoxin XII (156) that displayed quorum sensing inhibition (MICs 30 and $20 \mu \mathrm{g} /$ well, respectively) in the well diffusion assay toward Chromobacterium violaceum CV026 [80].

\subsection{Cytotoxic Activity}

Cancer is a leading cause of death in the world, accounting for $\approx 10$ million deaths in 2020 [81]. Its treatments include radiation therapy, surgical intervention, chemotherapy, or a combination of these options [82]. There are many available therapeutics for treating various types of cancer, however, none of them are totally safe and effective. Many of the reported naphthalenones have been assessed for cytotoxic effectiveness toward various cancer cell lines. Wang et al. separated 1, 4, 9, and 21 from the liquid cultures of Alternaria sp. harbored Morinda officinalis that showed weak activity ( $\mathrm{IC}_{50} \geq 200 \mu \mathrm{M}$ ) toward NCI-H460 (human lung carcinoma cell line), MCF-7 (human breast cancer cell line), SF-268 (human glioblastoma cell line), and HepG-2 in the SRB (sulforhodamine B) assay compared with cisplatin [83]. Compounds 8 and $\mathbf{9}$ obtained from the culture broth of Penicillium diversum var. aureum inhibited the growth of Yoshida sarcoma cells in tissue culture at concentrations 
20-25 $\mu \mathrm{g} / \mathrm{mL}$ [84]. Also, El-Amrani et al. separated $\mathbf{1}$ and 21 from Aureobasidium pullulans that did not have anti-proliferative activity toward L5178Y (mouse lymphoma cell line) in the MTT (3-(4, 5-dimethylthiazolyl-2)-2, 5-diphenyltetrazolium bromide) assay [85]. Additionally, 9 was purified from a marine-derived Aspergillus fumigatus extract by ODS column chromatography and HPLC. It exhibited notable cytotoxicity (Conc. $60 \mu \mathrm{M}$ ) toward MCF-7 after $24 \mathrm{~h}$ incubation. It was found to suppress MMP (mitochondrial membrane potential)-2,-9 expressions via attenuation of the MAPK (mitogen-activated protein kinase) signaling pathway. It also significantly reduced cell mobility and prohibited JNK (cJun $\mathrm{NH}_{2}$-terminal kinase), ERK (extracellular signal-regulated protein kinase), and P38 (p38 mitogen-activated protein kinase) phosphorylation, involved in cell migration and proliferation. Moreover, it remarkably up-regulated p53 (nuclear transcription factor with a pro-apoptotic function) and down-regulated CDK (cyclin-dependent kinase)4, CDK2, and cyclins (B1 and E). Hence, 9 could be a potential therapeutic for breast cancer [58]. However, it was inactive toward SW-620 and MDA-MB-435 (human melanoma cancer) cell lines in the MTT assay [59]. Compound 17 exhibited moderate cytotoxic potential toward L1210 (mouse lymphocytic leukemia cell line) $\left(\mathrm{IC}_{50} 100 \mu \mathrm{g} / \mathrm{mL}\right)$ and was inactive toward RBL-1 (rat basophilic leukemia cell line), HeLa S3 (human cervix carcinoma cell line), and BHK 21 (fibroblast baby hamster kidney cell line) $\left(\mathrm{IC}_{50}>100 \mu \mathrm{g} / \mathrm{mL}\right)$ in the microtiter plate assay. On the other hand, 2 was moderately active versus RBL-1, L1210, and BHK 21 (IC 50 25-50 $\mathrm{gg} / \mathrm{mL})$ and inactive toward the HeLa S3 cell line $\left(\mathrm{IC}_{50}>100 \mu \mathrm{g} / \mathrm{mL}\right)$ [35].

The cytotoxic activities of 9, 13, 14, 22, 28, and 31 toward BCA (human breast cancer), Vero (African green monkey kidney fibroblasts), NCI-H187 (human small cell lung cancer), and KB (human epidermoid carcinoma) were assessed by Pittayakhajonwut et al. using the MTT and SRB methods. Compounds 13 and 22 showed significant cytotoxic potential versus NCI-H187cell line ( $\mathrm{IC}_{50} \mathrm{~s} 2.86$ and $5.55 \mu \mathrm{g} / \mathrm{mL}$, respectively) in comparison to doxorubicin and ellipticine ( $\mathrm{IC}_{50} \mathrm{~s} 0.02$ and $0.32 \mu \mathrm{g} / \mathrm{mL}$, respectively). Additionally, 22 had remarkable cytotoxicity toward BCA ( $\left.\mathrm{IC}_{50} 2.96 \mu \mathrm{g} / \mathrm{mL}\right)$, compared with ellipticine and doxorubicin ( $\mathrm{IC}_{50} \mathrm{~s} 0.11$ and $0.21 \mu \mathrm{g} / \mathrm{mL}$, respectively). The other compounds were moderately active toward the tested cell lines ( $\mathrm{IC}_{50}$ ranging from 7.24 to $41.84 \mu \mathrm{g} / \mathrm{mL}$ ) [61]

Compounds 18 and 29 were separated from Phomopsis sp. sh917 harbored Isodon eriocalyx var. laxiflora stems. Their absolute configurations $3 \mathrm{R}$ for $\mathbf{1 8}$ and $3 \mathrm{R}, 4 \mathrm{~S}$ of 29 were confirmed based on CD, X-ray, or optical rotation comparison. Compound 29 had no obvious inhibitory effect on the viability of HUVECs (human umbilical vascular endothelial cells) $\left(\mathrm{IC}_{50}>100 \mu \mathrm{M}\right)$ in the MTT assay [86].

The new naphthalenone derivative 62 , alongside 1,9 , and 43 isolated from Cladosporium sp. JJM22 accompanied with $C$. tagal had no cytotoxic effect $\left(\mathrm{IC}_{50}>10 \mu \mathrm{M}\right)$ in the MTT assay versus HeLa cell line, compared to epirubicin [65]. Compound 48 exhibited weak cytotoxic potential ( $\mathrm{IC}_{50} 25 \mu \mathrm{g} / \mathrm{mL}$ ) versus L1210 cells [44].

Botryosphaerone E (55) purified from Pyrenochaetopsis sp. MSX63693 had 3R,4S absolute configuration as confirmed via ECD calculations, using TDDFT (time-dependent density functional theory). It showed weak activity $\left(\mathrm{IC}_{50}>25 \mu \mathrm{M}\right)$ versus MDA-MB-435, MDA-MB-231 (human breast cancer cell line), and OVCAR3 (human ovarian cancer cell line) in the MTT assay [87]. The purification of Paraphoma sp. extract yielded the new metabolite, 4,6,8-trihydroxy-5-methyl-3,4-dihydronaphthalen-1(2H)-one (59), along with the known one, 21. The absolute configuration of 59 was determined as R at C-4 by CD spectra. Both compounds exhibited no cytotoxic influence toward HepG2 (human liver cancer cell line), MCF-7, and Hela ( $\left.\mathrm{IC}_{50}>40 \mu \mathrm{M}\right)$, compared with etoposide ( $\mathrm{IC}_{50} \mathrm{~s} 16.64$, 16.11, and $15.00 \mu \mathrm{M}$, respectively) in the MTT assay [88]. Compound 63, isolated from mantis-associated Daldinia eschscholzii, had powerful cytotoxic potential in the MTT assay toward mouse splenic lymphocytes $\left(\mathrm{IC}_{50} 21.27 \mu \mathrm{g} / \mathrm{mL}\right)$, in comparison to cyclosporine $\mathrm{A}$ $\left(\mathrm{IC}_{50} 11.2 \mu \mathrm{g} / \mathrm{mL}\right)$ [27].

Three new dihydronaphthalenones: 66, 67, and 69 were separated from Botryosphaeria sp. BCC 8200, where 66 and 69 were isolated as two mixtures of inseparable isomers. These metabolites had a weak cytotoxic influence toward MCF-7, NCI-H187, and KB cells and 
Vero cells in the resazurin and green fluorescent protein micro-plate assays, respectively, compared to ellipticine [68].

$\mathrm{Xu}$ et al. separated new metabolites, botryosphaerones A-D (53 and 94-96) from the fermentation culture of Botryosphaeria australis strain ZJ12-1A that exhibited no cytotoxic activities versus HepG-2, HeLa, and A549 (lung adenocarcinoma epithelial) cells (Conc. of $10 \mu \mathrm{g} / \mathrm{mL}$ ) in the MTT assay [74]. On the other hand, 98, 99, 104, 106, 107, 111, 112, and 114 exhibited weak to moderate cytotoxic activity toward NCI-H187, MCF-7, Vero, and KB cell lines $\left(\mathrm{IC}_{50} 5.38-31.69 \mu \mathrm{g} / \mathrm{mL}\right)$ in comparison to doxorubicin and ellipticine [75].

Two new derivatives; aspvanicin A (127) and its epimer aspvanicin B (128) were obtained from EtOAc extract of the co-culture of the endophytic fungus Aspergillus versicolor KU258497 with B. subtilis. Their configurations (3S,4S)-127 and (3S,4R)-128 were assigned by NMR and ECD analysis assisted by DFT conformational analysis and TDDFT-ECD calculations. Compound $\mathbf{1 2 8}$ had moderate cytotoxic potential toward L5178Y ( $\left.\mathrm{IC}_{50} 22.8 \mu \mathrm{M}\right)$, compared to kahalalide $\mathrm{F}\left(\mathrm{IC}_{50} 4.3 \mu \mathrm{M}\right)$ in the MTT assay [89].

A novel dihydronaphthalenone, phomonaphthalenone A (130) with unusual tetrahydropyran and tetrahydrofuran moieties at C-4a/C-10a and C-3/C-5a, respectively, was purified from Phomopsis sp. HCCB04730 solid cultures. Its 3R, 5S, and 10aS configuration was assigned based on the coupling constant and NOESY in combination with X-ray and CD analyses. It exhibited significant cytotoxicity versus A549, MDA-MB-231, and PANC-1 (human Pancreatic cancer cell line) ( $\mathrm{IC}_{50} \mathrm{~s} 92.5,64.2$, and $52.7 \mu \mathrm{g} / \mathrm{mL}$, respectively), compared to 5-fluorouracil ( $\mathrm{IC}_{50} \mathrm{~s} 75.0,47.0$, and $65.0 \mu \mathrm{g} / \mathrm{mL}$, respectively) in the MTT assay [90]. Compound $\mathbf{1 3 1}$ possessed weak anti-proliferative potential toward HUVEC ( $\left.\mathrm{GI}_{50} 98.4 \mu \mathrm{M}\right)$ and $\mathrm{K}-562$ (human leukemia cell line) $\left(\mathrm{GI}_{50} 85.5 \mu \mathrm{M}\right)$ cell lines [21].

Delitschiapyrone A (133), an $\alpha$-pyrone-naphthalenone derivative, having a new 6/6/7/5/6-fused ring system was purified from the solid culture of Delitschia sp. FL1581, inhabiting Serenoa repens leaves. It was characterized by spectroscopic data, $X$-ray, and ECD that proved the existence of a unique pentacyclic skeleton in which $\alpha$-pyrone and naphthalenone moieties were connected by a seven-membered carbocyclic ring. This compound showed cytotoxic activity toward MCF-7, H460, HepG2, and U2OS (human osteosarcoma cell line) ( $\mathrm{IC}_{50} \mathrm{~s} 35.5,12.9,12.3$, and $20.4 \mu \mathrm{M}$, respectively), using the Alamar Blue assay compared to cisplatin ( $\mathrm{IC}_{50} \mathrm{~S} 9.4,2.2,8.3$, and $6.4 \mu \mathrm{M}$, respectively) [28]. Compounds 57, 58, 101-103, 138, and 139 displayed no cytotoxicity versus A549, HeLa, and MCF-7 in the MTT assay (conc. $50 \mu \mathrm{M}$ ) [91] (Figure 7). Compound 147 and 157 ( $\mathrm{IC}_{50}$ s ranging from 11.4 to 72.5 $\mu \mathrm{M}$ for 147 and from 10.1 to $53.7 \mu \mathrm{M}$ for 157) had moderate cytotoxic potential toward K562, Huh-7, MCF-7, HL-60 (human promyelocytic leukemia cell line), U937, H1975, MOLT-4, BGC823, A549, and HeLa cell lines, compared to trichostatin A [77].

Zurlo et al. stated that $\mathbf{1 4 5}$ had marked anti-proliferative capacity versus HT-29, SW480, and CaCo-2, particularly versus HT-29. They indicated that the HT-29 cells' expo-

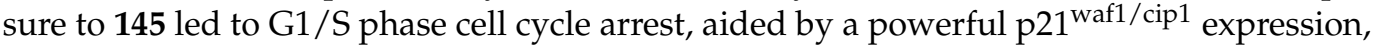
a remarkable down-regulation of $\mathrm{CDK} 2, \mathrm{CDK} 4$, and cyclins $\mathrm{E}$ and $\mathrm{D} 1$, and repression of CDK2 and CDK4 kinase activity [92]. This anti-proliferative potential toward HT-29 cells was induced through activating PPAR $\gamma$, leading to $\mathrm{p}^{2} 1^{\text {waf1/cip } 1}$ expression up-regulation and inducing $\beta$-catenin degradation, as well as impairment of TCF/ $\beta$-catenin pathway as evident by reduced cyclin D1 and c-Myc transcription. Finally, it induced the expression of E-cadherin, therefore, antagonizing invasion and metastasis [93]. Moreover, Koul et al. studied the cytotoxic potential of $\mathbf{1 4 5}$ separated from C. cladosporioides isolated from Datura innoxia toward MCF-7 cell lines. It was found that 145 induced microtubules depolymerization and sensitized programmed cell death through ROS-mediated autophagic flux, resulting in mitophagic cell death [94].

Marine sediments-derived C. cladosporioides HDN14-342 yielded $\mathbf{1 4 7}$ and 149-151 (Figure 8). Compounds 150 and 151 exhibited cytotoxic potential versus HCT-116, K562, and HeLa cell lines $\left(\mathrm{IC}_{50} \mathrm{~s} 3.9-23.0 \mu \mathrm{M}\right)$ in comparison to doxorubicin $\left(\mathrm{IC}_{50} \mathrm{~s} 0.2-0.8 \mu \mathrm{M}\right)$, whereas the other metabolites were inactive $\left(\mathrm{IC}_{50}>50.0 \mu \mathrm{M}\right)$ [95]. Li et al. purified six derivatives; 147, 150, and 152-155 from C. cladosporioides EN-399 and assessed their 
activities versus L02, H446, HeLa, A549, Huh7, SW1990, LM3, and MCF-7 in the MTT assay. It is noteworthy that 147, 152, and 153 had cytotoxic potential $\left(\mathrm{IC}_{50}\right.$ s ranging from 1.0 to $20.0 \mu \mathrm{M}$ ) toward most of the cell lines. Notably, 153 displayed cytotoxic capacity toward Huh7, A549, and LM3 cell lines ( $\mathrm{IC}_{50} \mathrm{~s} 1.0,5.0$, and $4.1 \mu \mathrm{M}$, respectively), compared to fluorouracil ( $\mathrm{IC}_{50} 6.2 \mu \mathrm{M}$ for Huh7) and cisplatin ( $\mathrm{IC}_{50} 9.1 \mu \mathrm{M}$ for $\mathrm{LM} 3$ and $1.3 \mu \mathrm{M}$ for A549), whereas 147 showed marked cytotoxic effect $\left(\mathrm{IC}_{50} 4.0 \mu \mathrm{M}\right)$ versus H446 similar to adriamycin $\left(\mathrm{IC}_{50} 4.0 \mu \mathrm{M}\right)$. These results indicated the dihydro-1,4-naphthoquinone nucleus was substantial for the activity (153 versus 150, 152, and 147, 154, and 155) and C-4 methoxyl intensified the effect (152 versus 155) [78]. Nevertheless, 154 (Conc. $100 \mu \mathrm{M}$ ) showed no noticeable activity versus HepG-2, SF-268, MCF-7, and NCI-H460 in the SRB assay [96].<smiles>O=C1CC[C@H](OC2CCC(=O)c3c(O)cccc32)c2c(O)cccc21</smiles>

135<smiles>O=C1CCC(OC2CC[C@@H](O)c3c(O)cccc32)c2c(O)cccc21</smiles>

136<smiles>O=C1CC[C@H](O[C@H]2CC[C@@H](O)c3cccc(O)c32)c2cccc(O)c21</smiles>

137<smiles>COc1cc2c(c(O)c1COC(C)c1c(O)c3c(c(O)c1C(C)OCc1c(O)cc4c(c1O)C(=O)CC[C@H]4O)C(=O)CC[C@@H]3O)C(=O)CC[C@@H]2O</smiles>

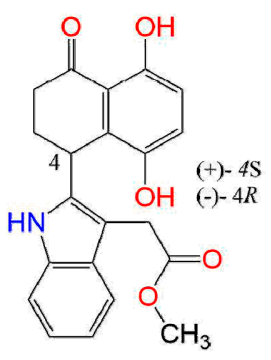

140<smiles></smiles>

141<smiles>O=C1CCC(c2ccc(O)c3cccc(O)c23)c2c(O)ccc(O)c21</smiles>

142<smiles>COc1cccc2c(O)ccc([C@@H]3CCC(=O)c4c(O)ccc(O)c43)c12</smiles>

143<smiles>COc1ccc(C2CCC(=O)c3c2ccc(O)c3O)c2c(OC)cccc12</smiles>

Figure 7. Structures of compounds 135-144. 
<smiles>CS(=O)(=O)CC[C@@H](c1cccc(O)c1C(=O)O)c1ccc(O)c2c1C(=O)[C@@H]1O[C@H]1[C@H]2O</smiles><smiles>C[As](C)(=O)CC[C@@]1(c2ccc(O)c3c2C(=O)[C@H]2O[C@H]2C3=O)C(=O)c2c(O)cccc21</smiles><smiles>O=C1CC[C@H](c2ccc(O)c3c2C(=O)CC[C@@H]3O)c2cccc(O)c21</smiles><smiles>C[As+](=O)CC[C@@H](c1cccc(O)c1)c1ccc(O)c2c1C(=O)C[C@@H](O)[C@H]2O</smiles><smiles>O=C1CC[C@H](c2ccc(O)c3c2C(=O)[C@H](O)[C@H](O)[C@H]3O)c2cccc(O)c21</smiles><smiles>CO[C@H]1CCC(=O)C2=C(C=CC=C1O)[C@H]1CC[C@H](OC)c3c(O)ccc1c32</smiles><smiles>O=C1CC[C@H](c2ccc(O)c3c2C(=O)C(Cl)[C@H](O)[C@H]3O)c2cccc(O)c21</smiles><smiles>CC(C)C(=O)CC[C@@H](c1cccc(O)c1)c1ccc(O)c2c1C(=O)CC[C@H]2O</smiles><smiles>CC(C)(C)CCC[C@@]1(c2ccc(O)c3c2C(=O)CCC3=O)C(=O)c2c(O)cccc21</smiles><smiles>CC(C)(C)[C@H]1CC[C@@H](c2ccc(O)c3c2[C@@H](O)CCC3=O)c2cccc(O)c21</smiles><smiles>CC(C)(C)CCC[C@@H](c1cccc(O)c1)c1ccc(O)c2c1C(=O)CC[C@H]2O</smiles><smiles>CC(C)(C)[13C]1=CC[C@H](c2ccc(O)c3c2C(O)CCC3=O)c2cccc(O)c21</smiles><smiles>O=C1C[C@@H](c2ccc(O)c3c2C(=O)[C@H](O)[C@H]2O[C@H]32)c2cccc(O)c21</smiles><smiles>CC(=O)C[C@]1(O)C(=O)c2c(O)ccc(C3CCC(=O)c4c(O)cccc43)c2C1=O</smiles>

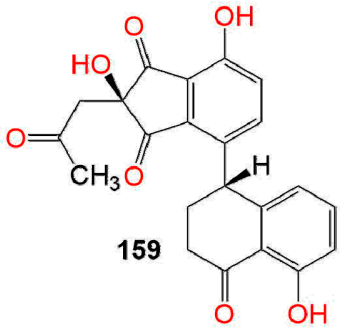

Figure 8. Structures of compounds 145-159.

\subsection{Antioxidant Activity}

Compounds 9 and 11 separated from Xylariaceous PSU-A80 were assessed for their antioxidant activity using the DPPH (1,1-diphenyl-2-picrylhydrazyl) assay. Compound 11 trapped DPPH radical with 2.65\% scavenging activity (Conc. $50 \mu \mathrm{g} / \mathrm{mL}$ ), whereas its methylated derivative 11 exhibited better activity than 9 [97]. Whilst 49 and 50 obtained from $A$. roseogriseum associated with the brown alga, Cladostephus spongius, exhibited weak activity with percentage radical scavenging of 2.8 and 12.1 at concentrations 100 and $500 \mu \mathrm{g} / \mathrm{mL}$, respectively, in the DPPH assay [98].

\subsection{Serotonin Antagonistic Activity}

Serotonin (5-HT) is a neurotransmitter in the central and peripheral nervous systems. It has been implicated in the etiology of various physio-pathological disorders such as anxiety, depression, schizophrenia, social phobia, IOP (intraocular pressure) modification, migraine, systemic and pulmonary hypertension, irritable bowel syndrome, vomiting, and eating disorders $[99,100]$. 5- $\mathrm{HT}_{2 \mathrm{C}}$ antagonists have been considered as a potential target for treating various health disorders [101]. Bös et al. reported the isolation of the first nitrogen-free 5-HT ligands; 46 and 47 from Aspergillus parvulus and assessed their binding affinity for $5-\mathrm{HT}_{2 \mathrm{c}}$ and $5-\mathrm{HT}_{2 \mathrm{~A}}$ human receptors, using displacement of $\left[{ }^{3} \mathrm{H}\right]-\mathrm{DOB}$ and $\left[{ }^{3} \mathrm{H}\right]-5-\mathrm{HT}$, respectively. It is noteworthy that they are preferably bound to the 5-HT2c receptor and displayed antagonistic capacities with $\mathrm{pKi}$ values 6.7 and 6.4, respectively. 
On the other hand, they could not displace $\left[{ }^{3} \mathrm{H}\right]-\mathrm{DOB}$ from the $5-\mathrm{HT}_{2 \mathrm{~A}}$ receptor binding site at Conc. up to $10 \mathrm{mM}$. It was found that the alkyl side chain was essential for binding, however, the phenolic $\mathrm{OH}$ was not implicated in binding to the receptor [102].

\subsection{Antiviral Activity}

The new naphthalenone derivatives; 74, 75, 78, and 80-82 were assessed for their antiviral activity toward Herpes simplex virus type I (HSV-1, strain KOS) and influenza virus A/WSN/33 (H1N1) at non-cytotoxic concentrations by a dye-uptake assay using neutral red. A remarkable activity for balticols D-F (80-82) was noticed toward HSV-1 ( $\mathrm{IC}_{50} \mathrm{~s}$ 0.1, 0.01, and $0.1 \mu \mathrm{g} / \mathrm{mL}$, respectively), compared to aciclovir (IC50 $0.1 \mu \mathrm{g} / \mathrm{mL}$ ). The other balticols A-C had moderate activity against HSV-1 ( $\left.\mathrm{IC}_{50} 1.0 \mu \mathrm{g} / \mathrm{mL}\right)$. Whilst 75, 78, 80, and 82 exhibited activities toward $\mathrm{H} 1 \mathrm{~N} 1$ ( $\mathrm{IC}_{50} \mathrm{~s} 10.0,1.0,0.1,1.0 \mu \mathrm{g} / \mathrm{mL}$, respectively), compared to amantadine sulphate $\left(\mathrm{IC}_{50} 15.0 \mu \mathrm{g} / \mathrm{mL}\right)$ [70]. Moreover, 130 displayed a significant HIV-1 inhibitory potential $\left(\mathrm{IC}_{50} 11.6 \mu \mathrm{g} / \mathrm{mL}\right)$ in the luciferase assay system using $293 \mathrm{~T}$ cells, compared with efavirenz ( $\left.\mathrm{IC}_{50} 4.7 \times 10^{-4} \mu \mathrm{g} / \mathrm{mL}\right)$ [90].

\subsection{Melanin Synthesis Inhibitory Activity}

Melanins are high molecular weight black or dark brown pigments commonly found in microorganisms, plants, and animals that are produced by oxidative polymerization [24]. They are not required for development and growth, but they enhance the competitiveness and survival of these species under conditions of electromagnetic and UV irradiation, high temperature, and desiccation [103]. Most fungal melanins are derived from DHN (1,8dihydroxynaphthalene) [24]. These pigments are correlated with the enhanced virulence of parasitic fungi and play a remarkable role in fungal pathogenic infections [104]. The newly isolated scytalols A-D (70-73) from the mycelial culture of Scytalidium sp. obtained from Basidiomycete infected body, growing on wood were assessed for their inhibitory effect on DHN (1,8-dihydroxynaphthalene) melanin biosynthesis using Lachnellula sp. A32-89 in the agar cultures. Only $\mathbf{7 0}$ and $\mathbf{7 3}$ selectively inhibited DHN melanin synthesis, however, 70 and 71 were inactive [105].

\subsection{Enzymes Inhibitory Activity}

The phytotoxic metabolite 3, which is an important intermediate in fungal melanin biosynthesis, was purified from Xylariaceae sp. SCSGAF0086 culture broth. It was found to show enzyme inhibitory potential toward PTPIB (protein-tyrosine phosphatase 1B), SHP2 (Src-homology 2 domain-containing phosphotyrosine phosphatase), and IMPDH (inosine monophosphate dehydrogenase) ( $\mathrm{IC}_{50} \mathrm{~s} 13.9,4.1$, and $41.2 \mu \mathrm{M}$, respectively), compared with mycophenolic acid ( $\mathrm{IC}_{50} 0.4 \mu \mathrm{M}$ for IMPDH) and ursolic acid ( $\mathrm{IC}_{50} \mathrm{~s} 2.8 \mu \mathrm{M}$ for PTPlB and SHP2). It is noteworthy that SHP2 is a target for anti-tumor agent screening and IMPDH and PTPIB are targets for screening immuno-suppressive and anti-diabetic agents, respectively. Therefore, 3 was a PTPIB and SHP2 inhibitor [106]. Wang et al. reported that 1 and 4 exhibited remarkable $\alpha$-glucosidase inhibitory potential compared to $\left(\mathrm{IC}_{50} \mathrm{~s} 34.88\right.$ and $102.34 \mu \mathrm{M}$, respectively) acarbose $\left(\mathrm{IC}_{50} 427.34 \mu \mathrm{M}\right)$ in the colorimetric assay, which could be beneficial for developing $\alpha$-glucosidase inhibitors [82].

IDO (indoleamine 2,3-dioxygenase) controls the rate-limiting steps in tryptophan (Trp) metabolism that is correlated with various disorders such as Parkinson's and Alzheimer's diseases and cataracts. Hence, it is considered a promising target for tumor immunotherapy [107]. Cui et al. separated and characterized a new metabolite; 54, together with 47, 53, and 95 from the $\mathrm{CH}_{2} \mathrm{Cl}_{2}$ extract of Neofusicoccum austral SYSU-SKSO24 obtained from Kandelia candel fresh branch. Compound 54 was like 53 with an extra methoxy group and had $3 R, 4 R$ configuration as evident by the ECD spectrum. Compounds 47, 53, and 95 (Conc. $40 \mu \mathrm{M}$ ) showed no IDO (indoleamine 2,3-dioxygenase) inhibitory activity, whereas 54 had relatively significant inhibitory potential $\left(\mathrm{IC}_{50} 6.36 \mu \mathrm{M}\right)$, compared with epacadostat $\left(\mathrm{IC}_{50} 0.5 \mu \mathrm{M}\right)$ in the fluorescence-based assay [107]. Xiao et al. reported the separation of a new derivative, $(2 S, 3 S, 4 S)$-8-dehydroxy-8-methoxyl-dihydronaphthalenone (97) and 
the formerly separated $\mathbf{8 8}$ and $\mathbf{9 8}$ from Fusarium sp. HP-2 isolated from "Qi-Nan" agarwood. Compound $\mathbf{9 7}$ had the same structure as $\mathbf{9 8}$, which was previously reported as a new metabolite, except for the existence of an additional methoxy group at C-8 [75]. Its configuration was assigned as $2 \mathrm{~S}, 3 \mathrm{~S}, 4 \mathrm{~S}$ based on the negative specific rotation as in $\mathbf{9 8}$. Only, 97 had a weak AChE (acetylcholinesterase) inhibitory activity (inhibition ratio 11.9\%, Conc. $50 \mu \mathrm{M} / \mathrm{mL}$ ) [108].

\subsection{Anti-Inflammatory Activity}

Inflammation is a host defense mechanism, which enables the body to survive during injury or infection and maintains the homeostasis of tissues in noxious conditions [109].

Endogenous nitric oxide (NO) plays a critical role in maintaining the homeostasis of varied cellular functions. NO local concentrations are highly dynamic as their synthesis is regulated by independent enzymatic pathways. NO has been shown to have a modulatory effect on inflammation, decreasing the secretion of pro-inflammatory cytokines in human alveolar macrophages challenged with bacterial lipopolysaccharides (LPS), while not altering the basal cytokine levels. Drugs used for managing inflammatory disorders relieve these ailments, but they may have serious life-threatening consequences [110-112]. Therefore, there is great enthusiasm for developing novel, safe therapeutics from natural sources for the treatment of inflammation. The reported studies revealed that the antiinflammatory potential of thiophenes could be due to the inhibition of the activation of the NF- $\mathrm{kB}$ (nuclear factor- $\mathrm{kB}$ ) pathway that regulates the expression of pro-inflammatory cytokines and chemokines [111]. A new $\beta$-tetralonyl glucoside; $\mathbf{1 2 9}$ was purified from the culture of Colletotrichum sp. GDMU-1 associated with Santalum album leaves. Compound 129 had $4^{\prime}$-methyl $\beta$-glucopyranose moiety linked at C-4. Enzymatic hydrolysis followed by ECD spectrum for the hydrolysis product sclerone (8) revealed an R-configuration at C-4. It possessed no inhibitory capacity on $\mathrm{NO}$ (nitric oxide) production elicited by LPS (lipopolysaccharide) in RAW264.7 cells [112]. The new metabolites; 57, 58, 101-103, 138, and 139 were purified from the marine-derived fungus Leptosphaerulina chartarum 3608. Both 102/103 and 57/101 were enantiomers as they had opposite optical rotations and Cotton effects in their CD spectra. Their configuration was assigned based on ECD. Compounds 58 and 138 were dimeric naphthalenones, consisting of two monomeric units; leptothalenone A (102/103) and 10-norparvulenone (58). Unfortunately, only 139 possessed moderate inhibitory potential on the LPS-induced NO production $\left(\mathrm{IC}_{50} 44.5 \mu \mathrm{M}\right)$ in the RAW264.7 cells using the Griess assay, compared to indomethacin ( $\left.\mathrm{IC}_{50} 37.5 \mu \mathrm{M}\right)$, however, the other metabolites ( $\left.\mathrm{IC}_{50}>100 \mu \mathrm{M}\right)$ had no significant anti-inflammatory activity [91]. In the anti-COX-2 assay, 148 and 157 revealed COX-2 inhibition ( $\mathrm{IC}_{50} \mathrm{~s} 60.2$ and $49.1 \mu \mathrm{M}$, respectively) upon comparison to indomethacin and NS-398 [77].

\subsection{Neuroprotective Activity}

Girich et al. studied the neuro-protective potential of 2 and 32 purified from the broth culture of Penicillium sp. KMM 4672 associated with Padina sp. (brown alga) in 6-OHDA (6-hydroxydopamine), paraquat, and rotenone-induced Parkinson's disease in Neuro-2a cells. They have been found to significantly increase the viability of paraquatand rotenone-treated Neuro-2a cells and decreased the elevated ROS level induced by these neurotoxins [113]. Five pairs of undescribed enantiomers, xylarinaps A-E (140144), including a pair of indole naphthalenones (140) and four pairs of naphthalenonenaphthalene dimers (141-144) were separated from the EtOAc of Xylaria nigripes. Their neuroprotective effects toward the OGD (oxygen and glucose deprivation)-induced damage to PC12 cells in the CCK-8 (cell counting kit-8) assay were assessed. They significantly promoted cell viability, decreased MDA (malondialdehyde) levels, and increased the SOD (superoxide dismutase) and GSHPx (glutathione peroxidase) levels, as well as further notably prohibited apoptosis, which could be the mode of their neuroprotective effect [29]. 


\subsection{Other Activities}

Corynenones A and B (51 and 52); new derivatives separated from Corynespora cassiicola XS-20090I7 were diastereoisomers, differing in the 3,4-diol centers' configuration; $3 S, 4 S$ for $\mathbf{5 1}$ and 3S,4R for $\mathbf{5 2}$ based on the ECD spectra and spectroscopic data. They had no antifouling potential toward the barnacle larval settlement using cyprids of Balanus amphitrite [114]. Compound 63 possessed a weak immunosuppressive effect in the T-cell viability assay $\left(\mathrm{IC}_{50}>10.0 \mu \mathrm{g} / \mathrm{mL}\right)$, in comparison to cyclosporine $\mathrm{A}\left(\mathrm{IC}_{50} 0.06 \mu \mathrm{g} / \mathrm{mL}\right.$ ) [89]. Moreover, in 2020, He et al. reported that $147\left(\mathrm{IC}_{50}>200 \mu \mathrm{M}\right)$ exhibited no anti-allergic potential toward RBL-2H3 cells, compared to loratadine (IC $5035.01 \mu \mathrm{M})$ [115].

\section{Conclusions}

In recent years, more metabolites have been discovered from fungi derived from diversified sources such as plants, animals, soil, and marine. The current review describes the naphthalenone derivatives reported from fungi, focusing on their biosynthesis and bioactivities. In fact, the available literature analysis revealed that a total of $\mathbf{1 5 9}$ naphthalenones with diverse chemical structures and various bioactivities were reported from 66 identified fungal genera and three unidentified genera. The largest number of derivatives have been obtained from Fusarium, Cladosporium, Daldinia, Biatriospora, Neofusicoccum, Leptosphaerulina, and Xylariaceae (Figure 9).

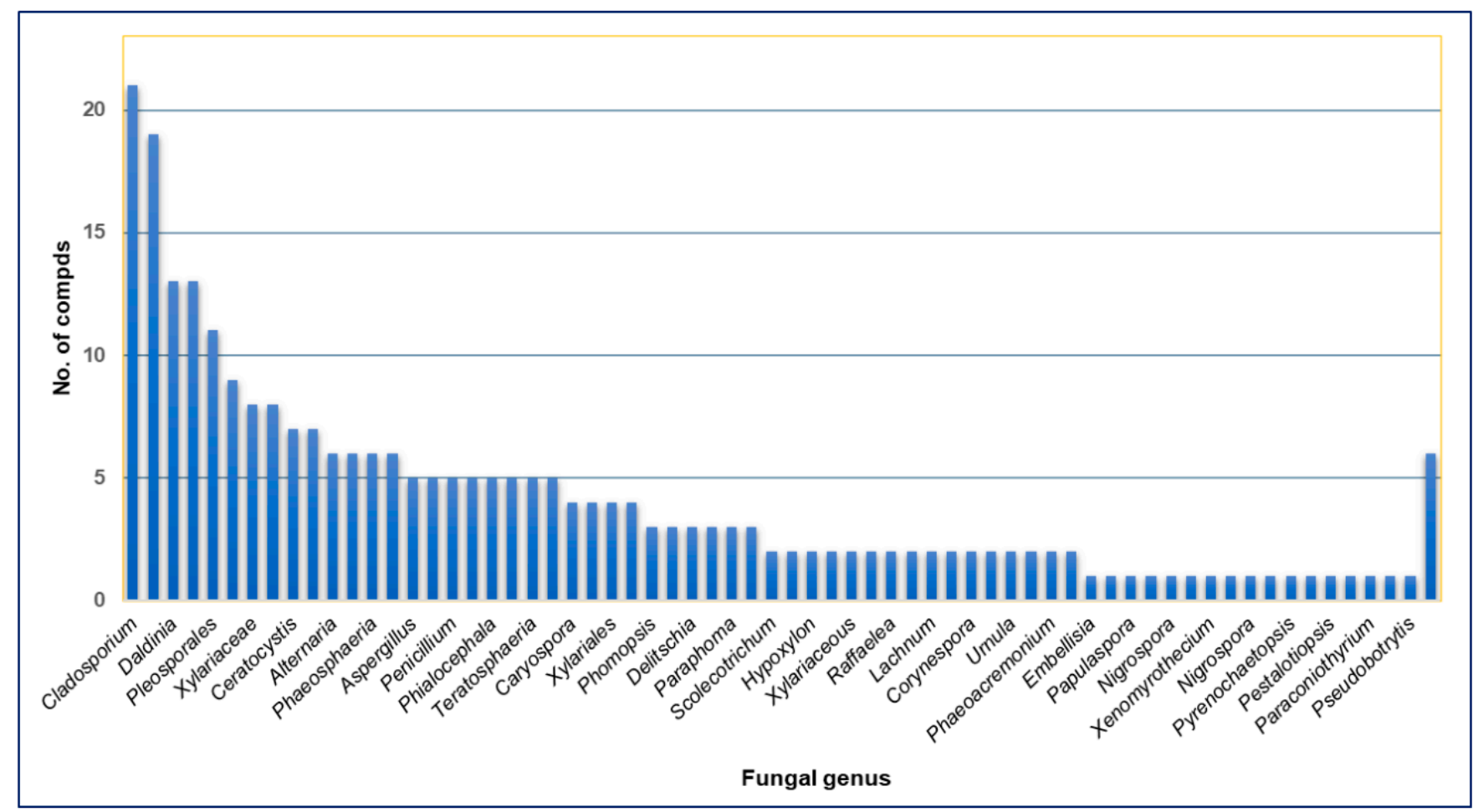

Figure 9. Numbers of naphthalenone derivatives reported from different fungal genera.

Compounds $1,3,8,9$, and 17 are the most commonly reported derivatives from various fungal genera. The majority of naphthalenones have been reported in the period from 2008 to 2020 (Figure 10). 


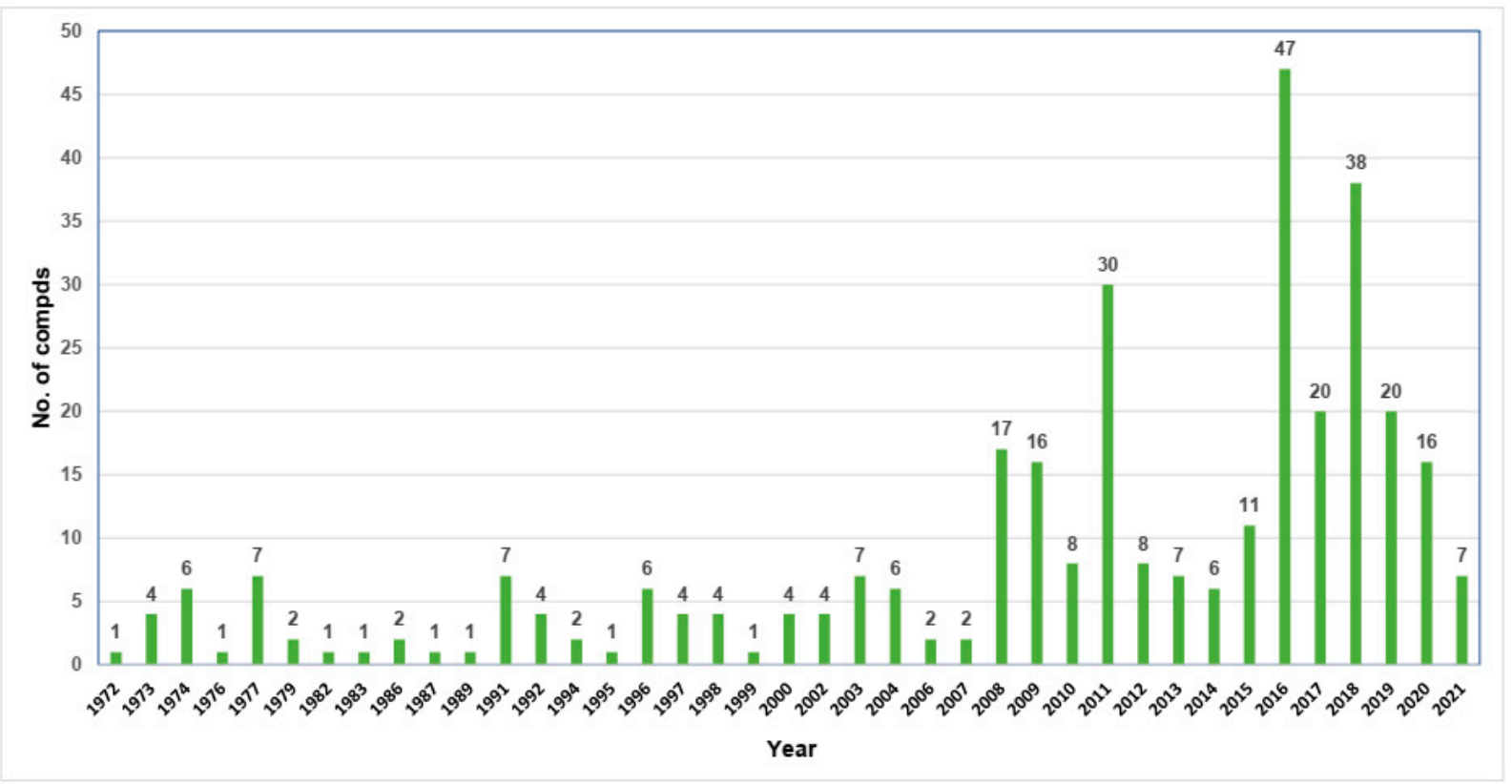

Figure 10. Numbers of naphthalenone derivatives reported by year.

This was due in part to limited knowledge of the fungal diversity and isolation and cultivation techniques that resulted in many fungal species remaining undiscovered [116]. The observed increase in the number of isolated derivatives can be attributed to the extensive application of new separation, screening, and characterization techniques. Also, the advances in the fungal cultivation strategies, as well as the wide array of genetic tools now available, allow for the fungal genome and metabolome to be readily exploited, leading to enhanced discovery of the value-added metabolites [117].

Many of the reported naphthalenones have remarkable phytotoxic potential. As such, they can be used as bioherbicides or as lead compounds for the synthesis of more efficacious phytotoxic compounds capable of targeting a wide range of weeds.

These metabolites have been assessed for antimicrobial, antimycobacterial, cytotoxic, nematocidal, antioxidant, serotonin antagonistic, antiviral, anti-inflammatory, neuroprotective, and anti-plasmodial, as well as melanin synthesis and enzyme inhibitory potential (Figure 11).

Some metabolites have shown promising activities that could be utilized as building blocks for the synthesis of various compounds for treating diverse human disorders. However, these metabolites remain to be further in-vivo tested for their bioactivities. Reports on naphthalenones indicated that differences in structural characteristics of derivatives often correlated with different bioactivities. For example, an increasing number of hydroxyl groups attached to the naphthalenone skeleton enhanced phytotoxic activity. It is noteworthy that compound 90 with a spirally linked $\gamma$-lactone ring at C-4 of the naphthalen$1(4 \mathrm{H})$-one moiety possessed potent antifungal potential than 91, 92, and 93 that have C-13 methyl ester, fused THF ring, and $\delta$-lactone ring, respectively. Also, 131 with an oxaneconnected binaphthyl ring system had a more powerful antimicrobial capacity than 63 and 65, which have C6-C7 fused furan rings. In the dimeric napthalenones, the C-4 $\alpha$ configured hydroxyl group was found to be essential for antimicrobial activity as in 147 and 149, however, its replacement with carbonyl (e.g., 153 and 154), methoxy group (150 and 152), or $\beta$-configured hydroxyl group reduced the activity (e.g., 155). In the cytotoxicity results, compound 13 with the C-3 methoxy group exhibited higher activity than its nonmethoxylated one (22). Additionally, it was revealed that the dihydro-1,4-naphthoquinone nucleus was substantial for the cytotoxic activity (e.g., 153 vs. 150, 152, and 147, 154, and 155) and the C-4 methoxy group intensified the effect (152 vs. 155). 


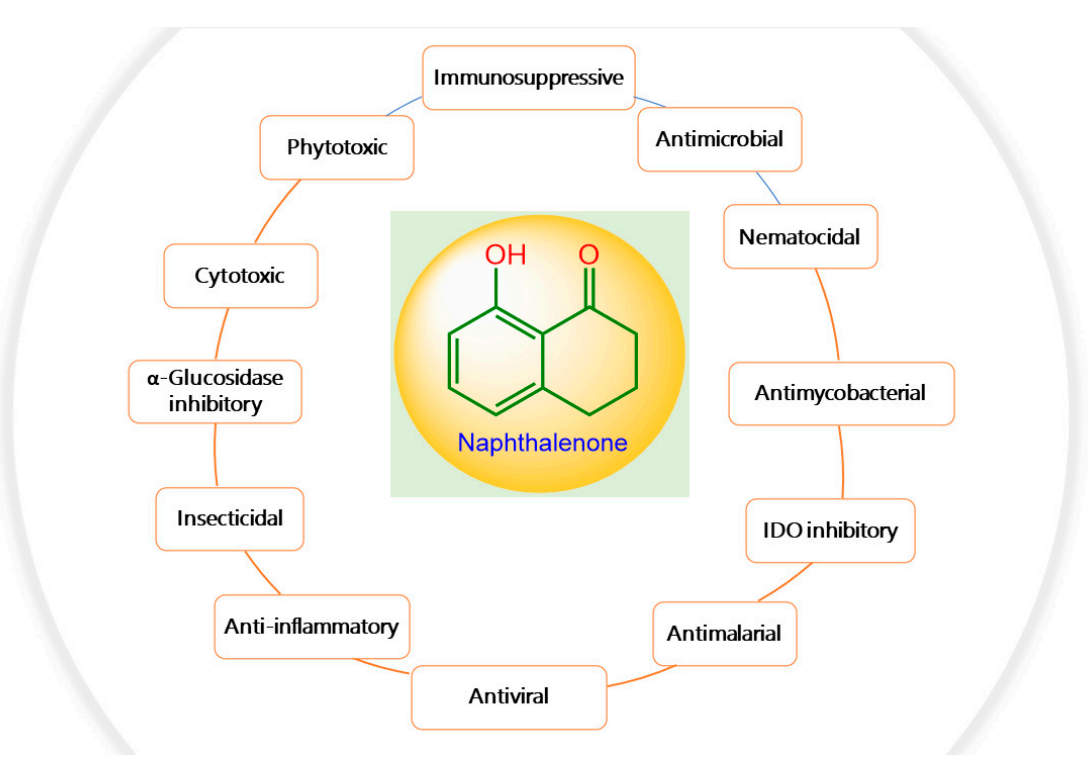

Figure 11. Promising biological activities of naphthalenone derivatives.

On the other hand, there are limited or no studies that focus on the mechanism of action of these metabolites. In addition, many of the reported metabolites have not been evaluated for their bioactivities, this may be due to either the lack of assays or not enough amount of the isolated compounds to perform these assays. Many of the tested metabolites had no substantial effectiveness in some evaluated bioactivities. Finally, assessment of other potential activities and derivatization of these compounds, as well as in-vivo and mechanistic studies of the active compounds should undoubtedly be the focus of future research.

Supplementary Materials: The following supporting information can be downloaded at: https:// www.mdpi.com/article/10.3390/toxins14020154/s1, Table S1: List of fungal naphthalenones (Fungal source, host, and place), Table S2: Biological activities of fungal naphthalenones. References [118-167] are cited in the supplementary materials.

Author Contributions: Conceptualization, S.R.M.I. and G.A.M. Resources, S.A.F., H.A.F., B.A.E. and S.G.A.M. Discussion of the contents S.A.F., H.A.F. and B.A.E., Writing-Original Draft Preparation, S.R.M.I., G.A.M., S.A.F., H.A.F., B.A.E. and S.G.A.M., Writing-Review and Editing, G.A.M. and S.R.M.I. All authors have read and agreed to the published version of the manuscript.

Funding: This research received no external funding.

Institutional Review Board Statement: Not applicable.

Informed Consent Statement: Not applicable.

Data Availability Statement: Not applicable.

Conflicts of Interest: The authors declare no conflict of interest.

\section{Abbreviations}

A549: Lung adenocarcinoma epithelial cell line; AChE: Acetylcholinesterase; B16 F-1: Mouse melanoma, producing melanin; BC: Human breast cancer; BCA: Human breast cancer; BEL-7402: Human hepatocellular carcinoma cell line; BHK 21: Fibroblast baby hamster kidney cell line; $\mathrm{CC}_{50}$ : 50\% cytotoxic concentration; CCK8: Cell Counting Kit-8; CDK: Cyclin-dependent kinase; DHN: 1,8-Dihydroxynaphthalene; DHN: 1,8-Dihydroxynaphthalene; DPPH: 1,1-Diphenyl-2-picrylhydrazyl; ECD: Electronic circular dichroism; ERK: Extracellular signal-regulated protein kinase; GFPMA: Green fluorescent protein microplate assay; $\mathrm{GI}_{50}$ : Concentration for $50 \%$ of maximal inhibition of cell proliferation; GSHPx: Glutathione peroxidase; H460: Human lung carcinoma cell line; HeLa $\mathrm{S}_{3}$ : 
Human cervix carcinoma cell line; HepG2: Human liver cancer cell line; HL-60: Human promyelocytic leukemia cell lines; HUVECs: Human umbilical vascular endothelial cells; IDO: Indoleamine 2,3-dioxygenase; IMPDH: Inosine monophosphate dehydrogenase; IZD: Inhibition zone diameter; JNK: c-Jun NH2-terminal kinase; K-562: Human leukemia cell lines; K-562: Human chronic myeloid cell lines; KB: Human epidermoid carcinoma, ATCC CCL-17; KB: Oral cavity cancer; L1210: Mouse lymphocytic leukemia cell line; L5178Y: Mouse lymphoma cell lines; LC 50 : Lethal concentration 50; MABA: Microplate Alamar blue assay; MAPK: Mitogen-activated protein kinases; MCF-7: Human breast cancer cell lines; MDA: Malondialdehyde; MDA-MB-231: Human breast cancer cell lines; MDA-MB-435: Human melanoma cancer cell lines; MMP: Mitochondrial membrane potential; mRNA: Messenger ribonucleic acid; MSH: Melanin stimulation hormone; MTT: 3-(4,5-Dimethylthiazol-2-yl)2,5-diphenyltetrazolium bromide; NCI-H187: Human small cell lung cancer; NCI-H460: Human lung carcinoma cell line; NO: Nitric oxide; OGD: Oxygen and glucose deprivation; OVCAR3: Human ovarian cancer cell lines; P38: p38 mitogen-activated protein kinases; P53: Nuclear transcription factor with a pro-apoptotic function; PANC-1: Human Pancreatic cancer cell lines; PTPIB: Protein tyrosine phosphatase 1B; RBL-1:Rat basophilic leukemia cell line; SF-268: Human glioblastoma cell line; SGC7901: Human gastric cancer cell line; SHP2: Src homology 2 domain-containing phosphotyrosine phosphatase; SOD: Superoxide dismutase; SRB: Sulforhodamine B; SRCD: Synchrotron radiation circular dichroism; T3HN: 1,3-8-trihydroxy naphthalene; T4HN: 1,3,6,8-Tetrahydroxynaphthalene; TDDFT: time-dependent density functional theory; U2OS: Human osteosarcoma cell line; VEGF: Vascular endothelial growth factor; Vero: African green monkey kidney fibroblasts; XTT: Cell proliferation kit II.

\section{References}

1. Hawksworth, D.L.; Lücking, R. Fungal diversity revisited: 2.2 to 3.8 million species. Microbiol. Spectr. 2017, 5. [CrossRef] [PubMed]

2. Ibrahim, S.R.M.; Altyar, A.E.; Mohamed, S.G.A.; Mohamed, G.A. Genus Thielavia: Phytochemicals, industrial importance and biological relevance. Nat. Prod. Res. 2021, 1-16. [CrossRef] [PubMed]

3. Ibrahim, S.R.M.; Mohamed, S.G.A.; Sindi, I.A.; Mohamed, G.A. Biologically active secondary metabolites and biotechnological applications of species of the family Chaetomiaceae (Sordariales): An updated review from 2016 to 2021. Mycol. Prog. 2021, 20, 595-639. [CrossRef]

4. Ibrahim, S.R.M.; Mohamed, S.G.A.; Altyar, A.E.; Mohamed, G.A. Natural Products of the Fungal Genus Humicola: Diversity, Biological Activity, and Industrial Importance. Curr. Microbiol. 2021, 78, 2488-2509. [CrossRef] [PubMed]

5. Ibrahim, S.R.M.; Sirwi, A.; Eid, B.G.; Mohamed, S.G.A.; Mohamed, G.A. Bright Side of Fusarium oxysporum: Secondary Metabolites Bioactivities and Industrial Relevance in Biotechnology and Nanotechnology. J. Fungi 2021, 7, 943. [CrossRef]

6. Ibrahim, S.R.; Mohamed, G.A.; Kamal, H.M.; Mohamed, S.G.; Khedr, A.I. Terretonins from Aspergillus Genus: Structures, Biosynthesis, Bioactivities, and Structural Elucidation. Mini-Rev. Org. Chem. 2022, 19, 257-269. [CrossRef]

7. Mohamed, G.A.; Ibrahim, S.R.M. Untapped potential of marine-associated Cladosporium species: An overview on secondary metabolites, biotechnological relevance, and biological activities. Mar. Drugs 2021, 19, 645. [CrossRef] [PubMed]

8. Srivastava, A.K. The role of fungus in bioactive compound production and nanotechnology. In Role of Plant Growth Promoting Microorganisms in Sustainable Agriculture and Nanotechnology; Woodhead Publishing: Cambridge, UK, $2019 ;$; p. 145.

9. Ibrahim, S.R.; Mohamed, G.A. Naphthylisoquinoline alkaloids potential drug leads. Fitoterapia 2015, 106, 194-225. [CrossRef]

10. Mohamed, G.A.; Ibrahim, S.R.M.; El Agamy, D.S.; Elsaed, W.M.; Sirwi, A.; Asfour, H.Z.; Koshak, A.E.; Elhady, S.S. Terretonin As A new protective agent against sepsis-induced qcute lung injury: Impact on SIRT1/Nrf2/NF-kBp65/NLRP3 signaling. Biology 2021, 10, 1219. [CrossRef]

11. Ibrahim, S.R.M.; Elkhayat, E.; Mohamed, G.A.A.; Fat'Hi, S.M.; Ross, S.A. Fusarithioamide A, a new antimicrobial and cytotoxic benzamide derivative from the endophytic fungus Fusarium chlamydosporium. Biochem. Biophys. Res. Commun. 2016, 479, 211-216. [CrossRef]

12. Ibrahim, P.S.R.; Mohamed, G.; Ahmed, H. Aegyoxepane: A New Oxepane Derivative from the Fungus Aspergillus aegyptiacus. Lett. Org. Chem. 2016, 13, 560-565. [CrossRef]

13. Ibrahim, S.R.M.; Mohamed, G.A. Naturally occurring naphthalenes: Chemistry, biosynthesis, structural elucidation, and biological activities. Phytochem. Rev. 2016, 15, 279-295. [CrossRef]

14. Ibrahim, P.S.R.; Mohamed, G.A.; Ross, S. Integracides F and G: New tetracyclic triterpenoids from the endophytic fungus Fusarium sp. Phytochem. Lett. 2016, 15, 125-130. [CrossRef]

15. Ibrahim, S.R.; Abdallah, H.M.; Mohamed, G.A.; Ross, S.A. Integracides H-J: New tetracyclic triterpenoids from the endophytic fungus Fusarium sp. Fitoterapia 2016, 112, 161-167. [CrossRef]

16. Ibrahim, S.R.M.; Mohamed, G.A.; Khedr, A.M.I. $\gamma$-Butyrolactones from Aspergillus species: Structures, biosynthesis, and biological activities. Nat. Prod. Commun. 2017, 12, 791-800. [CrossRef] 
17. Ibrahim, S.R.; Mohamed, G.A.; Al Haidari, R.A.; El-Kholy, A.A.; Zayed, M.F.; Khayat, M.T. Biologically active fungal depsidones: Chemistry, biosynthesis, structural characterization, and bioactivities. Fitoterapia 2018, 129, 317-365. [CrossRef]

18. Ibrahim, S.R.; Mohamed, G.A.; Al Haidari, R.; Zayed, M.; El-Kholy, A.A.; Elkhayat, E.; Ross, S.A. Fusarithioamide B, a new benzamide derivative from the endophytic fungus Fusarium chlamydosporium with potent cytotoxic and antimicrobial activities. Bioorg. Med. Chem. 2018, 26, 786-790. [CrossRef]

19. Ibrahim, P.S.R.; Abdallah, H.; Elkhayat, E.; Al Musayeib, N.M.; Asfour, H.Z.; Zayed, M.; Mohamed, G.A. Fusaripeptide A: New antifungal and anti-malarial cyclodepsipeptide from the endophytic fungus Fusarium sp. J. Asian Nat. Prod. Res. 2017, $20,75-85$. [CrossRef]

20. Ibrahim, S.R.M.; Sirwi, A.; Eid, B.G.; Mohamed, S.G.A.; Mohamed, G.A. Fungal depsides naturally inspiring molecules: Biosynthesis, structural characterization, and biological activities. Metabolites 2021, 11, 683. [CrossRef]

21. Barnes, E.C.; Jumpathong, J.; Lumyong, S.; Voigt, P.-D.D.K.; Hertweck, C. Daldionin, an Unprecedented Binaphthyl Derivative, and Diverse Polyketide Congeners from a Fungal Orchid Endophyte. Chem. A Eur. J. 2016, 22, 4551-4555. [CrossRef]

22. Xu, D.; Xue, M.; Shen, Z.; Jia, X.; Hou, X.; Lai, D.; Zhou, L. Phytotoxic Secondary Metabolites from Fungi. Toxins 2021, 13, 261. [CrossRef]

23. Andolfi, A.; Mugnai, L.; Luque, J.; Surico, G.; Cimmino, A.; Evidente, A. Phytotoxins Produced by Fungi Associated with Grapevine Trunk Diseases. Toxins 2011, 3, 1569-1605. [CrossRef] [PubMed]

24. Langfelder, K.; Streibel, M.; Jahn, B.; Haase, G.; Brakhage, A.A. Biosynthesis of fungal melanins and their importance for human pathogenic fungi. Fungal Genet. Biol. 2003, 38, 143-158. [CrossRef]

25. Watanabe, A.; Fujii, I.; Tsai, H.; Chang, Y.C.; Kwon-Chung, K.J.; Ebizuka, Y. Aspergillus fumigatus alb1 encodes naphthopyrone synthase when expressed in Aspergillus oryzae. FEMS Microbiol. Lett. 2000, 192, 39-44. [CrossRef] [PubMed]

26. Wheeler, M.H.; Stipanovic, R.D. Melanin biosynthesis and the metabolism of flaviolin and 2-hydroxyjuglone inWangiella dermatitidis. Arch. Microbiol. 1985, 142, 234-241. [CrossRef] [PubMed]

27. Zhang, Y.L.; Zhang, J.; Jiang, N.; Lu, Y.H.; Wang, L.; Xu, S.H.; Wang, W.; Zhang, G.F.; Xu, Q.; Ge, H.M.; et al. Immunosuppressive Polyketides from Mantis-AssociatedDaldinia eschscholzii. J. Am. Chem. Soc. 2011, 133, 5931-5940. [CrossRef] [PubMed]

28. Luo, J.G.; Wang, X.B.; Xu, Y.M.; U’Ren, J.M.; Arnold, A.E.; Kong, L.Y.; Gunatilaka, A.A. Delitschiapyrone A, a pyronenaphthalenone adduct bearing a new pentacyclic ring system from the leaf-associated fungus Delitschia sp. FL1581. Org. Lett. 2014, 16, 5944-5947. [CrossRef] [PubMed]

29. Li, J.; Li, L.-Q.; Long, H.-P.; Liu, J.; Jiang, Y.-P.; Xue, Y.; Wang, W.-X.; Tan, G.-S.; Gong, Z.-C.; Liu, J.-K. Xylarinaps A-E, five pairs of naphthalenone derivatives with neuroprotective activities from Xylaria nigripes. Phytochemistry 2021, 186, 112729. [CrossRef]

30. Fernández-Aparicio, M.; Delavault, P.; Timko, M.P. Management of Infection by Parasitic Weeds: A Review. Plants 2020, 9, 1184. [CrossRef]

31. Macías-Rubalcava, M.L.; Garrido-Santos, M.Y. Phytotoxic compounds from endophytic fungi. Appl. Microbiol. Biotechnol. 2022, 106, 931-950. [CrossRef]

32. Iwasaki, S.; Muro, H.; Nozoe, S.; Okuda, S.; Sato, Z. Isolation of 3,4-dihydro-3,4,8-trihydroxy-1(2H)-naphthalenone and tenuazonic acid from Pyricularia oryzae cavara. Tetrahedron Lett. 1972, 13, 13-16. [CrossRef]

33. Masi, M.; Meyer, S.; Górecki, M.; Mandoli, A.; Di Bari, L.; Pescitelli, G.; Cimmino, A.; Cristofaro, M.; Clement, S.; Evidente, A Pyriclins A and B, two monosubstituted hex-4-ene-2,3-diols and other phytotoxic metabolites produced by Pyricularia grisea isolated from buffelgrass (Cenchrus ciliaris). Chirality 2017, 29, 726-736. [CrossRef] [PubMed]

34. Semar, M.; Anke, H.; Arendholz, W.-R.; Veiten, R.; Steglich, W. Lachnellins A, B, C, D, and Naphthalene-1,3,8-triol, Biologically Active Compounds from a Lachnellula Species (Ascomycetes). Z. Naturforsch. C J. Biosci. 1996, 51, 500-512. [CrossRef] [PubMed]

35. Ayer, W.A.; Trifonov, L.S.; Hutchison, L.J.; Chakravarty, P. Metabolites from a Wood-Inhabiting Cup Fungus, Urnula craterium. Nat. Prod. Lett. 2000, 14, 405-410. [CrossRef]

36. Morita, T.; Aoki, H. Isosclerone, a New Metabolite of Sclerotinia sclerotiorum (LIB.) DE BARY. Agric. Biol. Chem. 1974, 38, 1501-1505. [CrossRef]

37. Venkatasubbaiah, P.; Chilton, W.S. Phytotoxins produced by Tubakia dryina. Mycopathologia 1992, 120, 33-37. [CrossRef]

38. Bürki, N.; Michel, A.; Tabacchi, R. Naphthalenones and isocoumarins of the fungus Ceratocystis fimbriata f. sp. platani. Mediterranna 2003, 14, 1-55. [CrossRef]

39. Stierle, A.A.; Upadhyay, R.; Hershenhorn, J.; Strobel, G.A.; Molina, G. The phytotoxins ofMycosphaerella fijiensis, the causative agent of Black Sigatoka disease of bananas and plantains. Experientia 1991, 47, 853-859. [CrossRef]

40. Gremaud, G.; Tabacchi, R. Relationship between the fungus Ceratocystis fimbriata coffea and the canker disease of the coffee tree. Phytochemistry 1996, 42, 1547-1549. [CrossRef]

41. Evidente, A.; Sparapano, L.; Andolfi, A.; Bruno, G. Two naphthalenone pentaketides from liquid cultures of Phaeoacremonium aleophilum, a fungus associated with esca of grapevine. Phytopathol. Mediterr. 2000, 39, 162-168.

42. Nakamura, T.; Supratman, U.; Harneti, D.; Maharani, R.; Koseki, T.; Shiono, Y. New compounds from Japanese oak wilt disease-associated fungus Raffaelea quercivora. Nat. Prod. Res. 2020, 35, 5304-5310. [CrossRef] [PubMed]

43. Shan, R.; Stadler, M.; Anke, H.; Sterner, O. Naphthalenone and Phthalide Metabolites from Lachnum papyraceum. J. Nat. Prod. 1997, 60, 804-805. [CrossRef] 
44. Cimmino, A.; Villegas-Fernández, A.M.; Andolfi, A.; Melck, D.; Rubiales, D.; Evidente, A. Botrytone, a New Naphthalenone Pentaketide Produced by Botrytis fabae, the Causal Agent of Chocolate Spot Disease on Vicia faba. J. Agric. Food Chem. 2011, 59, 9201-9206. [CrossRef] [PubMed]

45. Burruano, S.; Giambra, S.; Mondello, V.; Dellagreca, M.; Basso, S.; Tuzi, A.; Andolfi, A. Naphthalenone polyketides produced by Neofusicoccum parvum, a fungus associated with grapevine Botryosphaeria dieback. Phytopathol. Mediterr. 2016, 55, 197-206.

46. Masi, M.; Nocera, P.; Zonno, M.C.; Tuzi, A.; Pescitelli, G.; Cimmino, A.; Boari, A.; Infantino, A.; Vurro, M.; Evidente, A. Lentiquinones A, B, and C, Phytotoxic Anthraquinone Derivatives Isolated from Ascochyta lentis, a Pathogen of Lentil. J. Nat. Prod. 2018, 81, 2700-2709. [CrossRef]

47. Otomo, N.; Sato, H.; Sakamura, S. Novel phytotoxins produced by the causal fungus of the shoot blight of larches. Agric. Biol. Chem. 1983, 47, 1115-1119.

48. Abad, P.; Gouzy, J.; Aury, J.M.; Castagnone-Sereno, P.; Danchin, E.G.J.; Deleury, E.; Perfus-Barbeoch, L.; Anthouard, V.; Artiguenave, F.; Blok, V.C.; et al. Genome sequence of the metazoan plant-parasitic nematode Meloidogyne incognita. Nat. Biotechnol. 2008, 26, 909-915. [CrossRef]

49. Chen, J.; Song, B. Natural nematicidal active compounds: Recent research progress and outlook. J. Integrat. Agricul. 2021, 20, 2015-2031.

50. Dong, J.Y.; Song, H.C.; Li, J.H.; Tang, Y.S.; Sun, R.; Wang, L.; Zhou, Y.P.; Wang, L.M.; Shen, K.Z.; Wang, C.R.; et al. Ymf 1029A-E, Preussomerin Analogues from the Fresh-Water-Derived Fungus YMF 1.01029. J. Nat. Prod. 2008, 71, 952-956. [CrossRef]

51. Zhu, Y.; Dong, J.; Wang, L.; Zhou, W.; Li, L.; He, H.; Liu, H.; Zhang, K. Screening and isolation of antinematodal metabolites againstBursaphelenchus xylophilus produced by fungi. Ann. Microbiol. 2008, 58, 375-380. [CrossRef]

52. Prestinaci, F.; Pezzotti, P.; Pantosti, A. Antimicrobial resistance: A global multifaceted phenomenon. Pathog. Glob. Health 2015, 109, 309-318. [CrossRef] [PubMed]

53. Fair, R.J.; Tor, Y. Antibiotics and Bacterial Resistance in the 21st Century. Perspect. Med. Chem. 2014, 6, 25-64. [CrossRef] [PubMed]

54. Inácio, M.L.; Silva, G.H.; Teles, H.L.; Trevisan, H.C.; Cavalheiro, A.J.; Bolzani, V.D.S.; Young, M.C.; Pfenning, L.H.; Araújo, R. Antifungal metabolites from Colletotrichum gloeosporioides, an endophytic fungus in Cryptocarya mandioccana Nees (Lauraceae). Biochem. Syst. Ecol. 2006, 34, 822-824. [CrossRef]

55. Suleiman, M.; McGaw, L.; Naidoo, V.; Eloff, J. Detection of antimicrobial compounds by bioautography of different extracts of leaves of selected South African tree species. Afr. J. Tradit. Complement. Altern. Med. 2010, 7, 64-78. [CrossRef] [PubMed]

56. Findlay, J.A.; Kwan, D. Metabolites from a Scytalidium Species. Can. J. Chem. 1973, 51, 3299-3301. [CrossRef]

57. Li, Y.-X.; Himaya, S.; Dewapriya, P.; Kim, H.J.; Kim, S.-K. Anti-proliferative effects of isosclerone isolated from marine fungus Aspergillus fumigatus in MCF-7 human breast cancer cells. Process Biochem. 2014, 49, 2292-2298. [CrossRef]

58. El-Elimat, T.; Raja, H.A.; Figueroa, M.; Swanson, S.M.; Iii, J.O.F.; Lucas, D.M.; Grever, M.R.; Wani, M.C.; Pearce, C.J.; Oberlies, N.H. Sorbicillinoid analogs with cytotoxic and selective anti-Aspergillus activities from Scytalidium album. J. Antibiot. 2014, 68, 191-196. [CrossRef]

59. Lu, S.; Draeger, S.; Schulz, B.; Krohn, K.; Ahmed, I.; Hussain, H.; Yi, Y.; Li, L.; Zhang, W. Bioactive Aromatic Derivatives from Endophytic Fungus, Cytospora sp. Nat. Prod. Commun. 2011, 6, 661-666. [CrossRef]

60. Pittayakhajonwut, P.; Sohsomboon, P.; Dramae, A.; Suvannakad, R.; Lapanun, S.; Tantichareon, M. Antimycobacterial Substances from Phaeosphaeria sp BCC8292. Planta Med. 2008, 74, 281-286. [CrossRef]

61. Yuan, C.; Li, G.; Wu, C.-S.; Wang, H.-Y.; Zhao, Z.-T.; Lou, H.-X. A New Fatty Acid from the Endolichenic Fungus Massarina sp. Chem. Nat. Compd. 2015, 51, 415-417. [CrossRef]

62. Kim, K.H.; Beemelmanns, C.; Murillo, C.; Guillén, A.; Umaña, L.; Tamayo-Castillo, G.; Kim, S.-N.; Clardy, J.; Cao, S. Naphthalenones and Isocoumarins from a Costa Rican Fungus Xylariaceae sp. CR1546C. J. Chem. Res. 2014, 38, 722-725. [CrossRef]

63. Wu, J.-T.; Zheng, C.-J.; Zhang, B.; Zhou, X.-M.; Zhou, Q.; Chen, G.-Y.; Zeng, Z.-E.; Xie, J.-L.; Han, C.-R.; Lyu, J.-X. Two new secondary metabolites from a mangrove-derived fungus Cladosporium sp. JJM22. Nat. Prod. Res. 2018, 33, 34-40. [CrossRef] [PubMed]

64. Kongyen, W.; Rukachaisirikul, V.; Phongpaichit, S.; Sakayaroj, J. A new hydronaphthalenone from the mangrove-derived Daldinia eschscholtzii PSU-STD57. Nat. Prod. Res. 2015, 29, 1995-1999. [CrossRef] [PubMed]

65. Prabpai, S.; Wiyakrutta, S.; Sriubolmas, N.; Kongsaeree, P. Antimycobacterial dihydronaphthalenone from the endophytic fungus Nodulisporium sp. of Antidesma ghaesembilla. Phytochem. Lett. 2015, 13, 375-378. [CrossRef]

66. Sun, R.; Gao, Y.-X.; Shen, K.-Z.; Xu, Y.-B.; Wang, C.-R.; Liu, H.-Y.; Dong, J.-Y. Antimicrobial metabolites from the aquatic fungus Delitschia corticola. Phytochem. Lett. 2011, 4, 101-105. [CrossRef]

67. Isaka, M.; Yangchum, A.; Rachtawee, P.; Khoyaiklang, P.; Boonyuen, N.; Lumyong, S. Dihydronaphthalenones from the endophytic fungus Botryosphaeria sp. BCC 8200. Phytochem. Lett. 2009, 2, 207-210. [CrossRef]

68. Liu, C.H.; Meng, J.C.; Zou, W.X.; Huang, L.L.; Tang, H.Q.; Tan, R.X. Antifungal carbon skeleton from Keissleriella sp. Y4108, a marine filamentous fungus. Planta Med. 2002, 68, 363-365. [CrossRef]

69. Shushni, M.A.M.; Mentel, R.; Lindequist, U.; Jansen, R. Balticols A-F, New Naphthalenone Derivatives with Antiviral Activity, from an Ascomycetous Fungus. Chem. Biodivers. 2009, 6, 127-137. [CrossRef]

70. Sommart, U.; Rukachaisirikul, V.; Sukpondma, Y.; Phongpaichit, S.; Sakayaroj, J.; Kirtikara, K. Hydronaphthalenones and a Dihydroramulosin from the Endophytic Fungus PSU-N24. Chem. Pharm. Bull. 2008, 56, 1687-1690. [CrossRef] 
71. Trisuwan, K.; Khamthong, N.; Rukachaisirikul, V.; Phongpaichit, S.; Preedanon, S.; Sakayaroj, J. Anthraquinone, Cyclopentanone, and Naphthoquinone Derivatives from the Sea Fan-Derived Fungi Fusarium spp. PSU-F14 and PSU-F135. J. Nat. Prod. 2010, 73, 1507-1511. [CrossRef]

72. Feng, Y.; Wang, L.; Niu, S.; Li, L.; Si, Y.; Liu, X.; Che, Y. Naphthalenones from a Perenniporia sp. Inhabiting the Larva of a Phytophagous Weevil, Euops chinesis. J. Nat. Prod. 2012, 75, 1339-1345. [CrossRef] [PubMed]

73. Xu, Y.-H.; Lu, C.-H.; Zheng, Z.-H.; Shen, Y.-M. New Polyketides Isolated from Botryosphaeria australis Strain ZJ12-1A. Helvetica Chim. Acta 2011, 94, 897-902. [CrossRef]

74. Kornsakulkarn, J.; Dolsophon, K.; Boonyuen, N.; Boonruangprapa, T.; Rachtawee, P.; Prabpai, S.; Kongsaeree, P.; Thongpanchang, C. Dihydronaphthalenones from endophytic fungus Fusarium sp. BCC14842. Tetrahedron 2011, 67, 7540-7547. [CrossRef]

75. Amand, S.; Vallet, M.; Guedon, L.; Genta-Jouve, G.; Wien, F.; Mann, S.; Dupont, J.; Prado, S.; Nay, B. A Reactive Eremophilane and Its Antibacterial 2(1H)-Naphthalenone Rearrangement Product, Witnesses of a Microbial Chemical Warfare. Org. Lett. 2017, 19, 4038-4041. [CrossRef]

76. Ai, W.; Lin, X.; Wang, Z.; Lü, X.; Mangaladoss, F.; Yang, X.; Zhou, X.; Tu, Z.; Liu, Y. Cladosporone A, a new dimeric tetralone from fungus Cladosporium sp. KcFL6' derived of mangrove plant Kandelia candel. J. Antibiot. 2014, 68, 213-215. [CrossRef] [PubMed]

77. Li, H.-L.; Li, X.-M.; Mándi, A.; Antus, S.; Li, X.; Zhang, P.; Liu, Y.; Kurtán, T.; Wang, B.-G. Characterization of Cladosporols from the Marine Algal-Derived Endophytic Fungus Cladosporium cladosporioides EN-399 and Configurational Revision of the Previously Reported Cladosporol Derivatives. J. Org. Chem. 2017, 82, 9946-9954. [CrossRef] [PubMed]

78. Bai, M.; Zheng, C.-J.; Tang, D.-Q.; Zhang, F.; Wang, H.-Y.; Chen, G.-Y. Two new secondary metabolites from a mangrove-derived fungus Cladosporium sp. JS1-2. J. Antibiot. 2019, 72, 779-782. [CrossRef]

79. Zhang, F.; Zhou, L.; Kong, F.; Ma, Q.; Xie, Q.; Li, J.; Dai, H.; Guo, L.; Zhao, Y. Altertoxins with Quorum Sensing Inhibitory Activities from The Marine-Derived Fungus Cladosporium sp. KFD33. Mar. Drugs 2020, 18, 67. [CrossRef]

80. Ferlay, J.; Ervik, M.; Lam, F.; Colombet, M.; Mery, L.; Piñeros, M.; Znaor, A.; Soerjomataram, I.; Bray, F. Global Cancer Observatory: Cancer Today. Lyon: International Agency for Research on Cancer. 2020. Available online: https://gco.iarc.fr/today (accessed on 25 December 2021)

81. Senapati, S.; Mahanta, A.K.; Kumar, S.; Maiti, P. Controlled drug delivery vehicles for cancer treatment and their performance. Signal Transduct. Target. Ther. 2018, 3, 7. [CrossRef]

82. Wang, Y.; Liu, H.-X.; Chen, Y.-C.; Sun, Z.-H.; Li, H.-H.; Li, S.-N.; Yan, M.-L.; Zhang, W.-M. Two New Metabolites from the Endophytic Fungus Alternaria sp. A744 Derived from Morinda officinalis. Molecules 2017, 22, 765. [CrossRef]

83. Fujimoto, Y.; Yokoyama, E.; Takahashi, T.; Uzawa, J.; Morooka, N.; Tsunoda, H.; Tatsuno, T. Studies on the metabolites of Penicillium diversum var. aureum. I. Chem. Pharm. Bull. 1986, 34, 1497-1500. [CrossRef] [PubMed]

84. El-Amrania, M.; Ebadab, S.S.; Gadb, H.A.; Proksch, P. Pestalotiopamide E and pestalotiopin B from an endophytic fungus Aureobasidium pullulans isolated from Aloe vera leaves. Phytochem. Lett. 2016, 18, 95-98. [CrossRef]

85. Tang, J.-W.; Wang, W.-G.; Li, A.; Yan, B.-C.; Chen, R.; Li, X.-N.; Du, X.; Sun, H.-D.; Pu, J.-X. Polyketides from the endophytic fungus Phomopsis sp. sh917 by using the one strain/many compounds strategy. Tetrahedron 2017, 73, 3577-3584. [CrossRef]

86. Flores-Bocanegra, L.; Raja, H.A.; Bacon, J.W.; Maldonado, A.C.; Burdette, J.E.; Pearce, C.J.; Oberlies, N.H. Cytotoxic Naphthoquinone Analogues, Including Heterodimers, and Their Structure Elucidation Using LR-HSQMBC NMR Experiments. J. Nat. Prod. 2020, 84, 771-778. [CrossRef] [PubMed]

87. Li, L.Y.; Sun, B.D.; Zhang, G.S.; Deng, H.; Wang, M.H.; Tan, X.M.; Zhang, X.Y.; Jia, H.M.; Zhang, H.W.; Zhang, T.; et al. Polyketides with different post-modifications from desert endophytic fungus Paraphoma sp. Nat. Prod. Res. 2017, 32, 939-943. [CrossRef] [PubMed]

88. Abdelwahab, M.F.; Kurtán, T.; Mándi, A.; Müller, W.E.G.; Fouad, M.A.; Kamel, M.S.; Liu, Z.; Ebrahim, W.; Daletos, G.; Proksch, P. Induced secondary metabolites from the endophytic fungus Aspergillus versicolor through bacterial co-culture and OSMAC ap-proaches. Tetrahedron Lett. 2018, 59, 2647-2652. [CrossRef]

89. Yang, Z.; Ding, J.; Ding, K.; Chen, D.; Cen, S.; Ge, M. Phomonaphthalenone A: A novel dihydronaphthalenone with anti-HIV activity from Phomopsis sp. HCCB04730. Phytochem. Lett. 2013, 6, 257-260. [CrossRef]

90. Zhang, P.; Jia, C.; Lang, J.; Li, J.; Luo, G.; Chen, S.; Yan, S.; Liu, L. Mono- and Dimeric Naphthalenones from the Marine-Derived Fungus Leptosphaerulina chartarum 3608. Mar. Drugs 2018, 16, 173. [CrossRef]

91. Zurlo, D.; Leone, C.; Assante, G.; Salzano, S.; Renzone, G.; Scaloni, A.; Foresta, C.; Colantuoni, V.; Lupo, A. Cladosporol a stimulates G1-phase arrest of the cell cycle by up-regulation of p21waf1/cip1 expression in human colon carcinoma HT-29 cells. Mol. Carcinog. 2013, 52, 1-17. [CrossRef]

92. Zurlo, D.; Assante, G.; Moricca, S.; Colantuoni, V.; Lupo, A. Cladosporol A, a new peroxisome proliferator-activated receptor $\gamma$ $($ PPAR $\gamma$ ) ligand, inhibits colorectal cancer cells proliferation through $\beta$-catenin/TCF pathway inactivation. Biochim. Biophys. Acta 2014, 1840, 2361-2372. [CrossRef]

93. Koul, M.; Kumar, A.; Deshidi, R.; Sharma, V.; Singh, R.D.; Singh, J.; Sharma, P.R.; Shah, B.A.; Jaglan, S.; Singh, S.; et al. Cladosporol A triggers apoptosis sensitivity by ROS-mediated autophagic flux in human breast cancer cells. BMC Cell Biol. 2017, 18, 26. [CrossRef]

94. Zhang, Z.; He, X.; Liu, C.; Che, Q.; Zhu, T.; Gu, Q.; Li, D. Clindanones A and B and cladosporols F and G, polyketides from the deep-sea derived fungus Cladosporium cladosporioides HDN14-342. RSC Adv. 2016, 6, 76498-76504. [CrossRef] 
95. Fan, Z.; Sun, Z.-H.; Liu, H.; Chen, Y.-C.; Li, H.-H.; Zhang, W.-M. Perangustols A and B, a pair of new azaphilone epimers from a marine sediment-derived fungus Cladosporium perangustm FS62. J. Asian Nat. Prod. Res. 2016, 18, 1024-1029. [CrossRef] [PubMed]

96. Rukachaisirikul, V.; Sommart, U.; Phongpaichit, S.; Hutadilok-Towatana, N.; Rungjindamai, N.; Sakayaroj, J. Metabolites from the Xylariaceous Fungus PSU-A80. Chem. Pharm. Bull. 2007, 55, 1316-1318. [CrossRef] [PubMed]

97. Abdel-Lateff, A.; König, G.M.; Fisch, K.M.; Höller, U.; Jones, P.G.; Wright, A.D. New Antioxidant Hydroquinone Derivatives from the Algicolous Marine Fungus Acremonium sp. J. Nat. Prod. 2002, 65, 1605-1611. [CrossRef]

98. Ibrahim, S.R.M.; Mohamed, G.A.; El-Messery, S.M. In silico Modeling Studies of 5-HT2B Antagonistic Activity of 2-(2phenylethyl)chromone Derivatives from Cucumis melo Seeds. Lett. Drug Des. Discov. 2016, 13, 840-844. [CrossRef]

99. Costagliola, C.; Parmeggiani, F.; Semeraro, F.; Sebastiani, A. Selective Serotonin Reuptake Inhibitors: A Review of its Effects on Intraocular Pressure. Curr. Neuropharmacol. 2008, 6, 293-310. [CrossRef]

100. Peng, Y.; Zhao, S.; Wu, Y.; Cao, H.; Xu, Y.; Liu, X.; Shui, W.; Cheng, J.; Zhao, S.; Shen, L.; et al. Identification of natural products as novel ligands for the human 5-HT2C receptor. Biophys. Rep. 2018, 4, 50-61. [CrossRef]

101. Bös, M.; Canesso, R.; Inoue-Ohga, N.; Nakano, A.; Takehana, Y.; Sleight, A.J. O-Methylasparvenone, a nitrogen-free serotonin antagonist. Bioorg. Med. Chem. 1997, 5, 2165-2171. [CrossRef]

102. Bell, A.A.; Wheeler, M.H. Biosynthesis and functions of fungal melanins. Annu. Rev. Phytopathol. 1986, 24, 411-451. [CrossRef]

103. Lee, J.-K.; Jung, H.-M.; Kim, S.-Y. 1,8-Dihydroxynaphthalene (DHN)-Melanin Biosynthesis Inhibitors Increase Erythritol Production in Torula corallina, and DHN-Melanin Inhibits Erythrose Reductase. Appl. Environ. Microbiol. 2003, 69, 3427-3434. [CrossRef] [PubMed]

104. Thines, E.; Anke, H.; Sterner, O. Scytalols A, B, C, and D and other modulators of melanin biosynthesis from Scytalidium sp 36-93. J. Antibiot. 1998, 51, 387-393. [CrossRef] [PubMed]

105. Nong, X.-H.; Zheng, Z.-H.; Zhang, X.-Y.; Lu, X.-H.; Qi, S.-H. Polyketides from a Marine-Derived Fungus Xylariaceae sp. Mar. Drugs 2013, 11, 1718-1727. [CrossRef] [PubMed]

106. Cui, H.; Zhang, H.; Liu, Y.; Gu, Q.; Xu, J.; Huang, X.; She, Z. Ethylnaphthoquinone derivatives as inhibitors of indoleamine-2, 3-dioxygenase from the mangrove endophytic fungus Neofusicoccum austral SYSU-SKS024. Fitoterapia 2018, 125, $281-285$. [CrossRef]

107. Xiao, W.-J.; Chen, H.-Q.; Wang, H.; Cai, C.-H.; Mei, W.-L.; Dai, H.-F. New secondary metabolites from the endophytic fungus Fusarium sp. HP-2 isolated from “Qi-Nan" agarwood. Fitoterapia 2018, 130, 180-183. [CrossRef]

108. Medzhitov, R. Inflammation 2010: New Adventures of an Old Flame. Cell 2010, 140, 771-776. [CrossRef]

109. Yatoo, M.I.; Gopalakrishnan, A.; Saxena, A.; Parray, O.R.; ALAM Tufani, N.; Chakraborty, S.; Tiwari, R.; Dhama, K.; Iqbal, H. Anti-Inflammatory Drugs and Herbs with Special Emphasis on Herbal Medicines for Countering Inflammatory Diseases and Disorders-A Review. Recent Patents Inflamm. Allergy Drug Discov. 2018, 12, 39-58. [CrossRef]

110. Fizeșan, I.; Rusu, M.E.; Georgiu, C.; Pop, A.; Ștefan, M.G.; Muntean, D.M.; Mirel, S.; Vostinaru, O.; Kiss, B.; \& Popa, D.S Antitussive, Antioxidant, and Anti-Inflammatory Effects of a Walnut (Juglans regia L.) Septum Extract Rich in Bioactive Compounds. Antioxidants 2021, 10, 119. [CrossRef]

111. Liu, W.; Chen, S.; Li, J.; Yang, X.; Yan, C.; Liu, H. A new $\beta$-tetralonyl glucoside from the Santalum album derived endophytic fungus Colletotrichum sp. GDMU-1. Nat. Prod. Res. 2018, 33, 354-359. [CrossRef]

112. Girich, E.V.; Yurchenko, A.N.; Smetanina, O.F.; Trinh, P.T.H.; Ngoc, N.T.D.; Pivkin, M.V.; Popov, R.S.; Pislyagin, E.A.; Menchinskaya, E.S.; Chingizova, E.A.; et al. Neuroprotective Metabolites from Vietnamese Marine Derived Fungi of Aspergillus and Penicillium Genera. Mar. Drugs 2020, 18, 608. [CrossRef]

113. Zhao, D.-L.; Shao, C.-L.; Wang, C.-Y.; Wang, M.; Yang, L.-J.; Wang, C.-Y. Naphthalenones and Depsidones from a Sponge-Derived Strain of the Fungus Corynespora cassiicola. Molecules 2016, 21, 160. [CrossRef] [PubMed]

114. He, Z.H.; Zhang, G.; Yan, Q.X.; Zou, Z.B.; Xiao, H.X.; Xie, C.L.; Tang, X.X.; Luo, L.Z.; Yang, X.W. Cladosporactone A, a unique polyketide with 7-methylisochromen-3-one skeleton from the deep-sea-derived fungus Cladosporium cladosporioides. Chem. Biodivers. 2020, 17, e2000158. [CrossRef] [PubMed]

115. Zhong, J.-J.; Xiao, J.-H. Secondary Metabolites from Higher Fungi: Discovery, Bioactivity, and Bioproduction. Adv. Biochem. Eng. Biotechnol. China I 2009, 113, 79-150. [CrossRef]

116. Keller, N.P. Fungal secondary metabolism: Regulation, function and drug discovery. Nat. Rev. Microbiol. 2019, 17, 167180 [CrossRef] [PubMed]

117. Wu, B.; Hussain, M.; Zhang, W.; Stadler, M.; Liu, X.; Xiang, M. Current insights into fungal species diversity and perspective on naming the environmental DNA sequences of fungi. Mycology 2019, 10, 127-140. [CrossRef]

118. Hemingway, R.W.; McGraw, G.W.; Barras, S.J. Polyphenols in Ceratocystis minor infected Pinus taeda: Fungal metabolites, phloem and xylem phenols. J. Agric. Food Chem. 1977, 25, 717-723. [CrossRef]

119. Stipanovic, R.D.; Bell, A.A. Pentaketide metabolites of Verticillium dahliae. II. Accumulation of naphthol derivatives by the aberrant-melanin mutant BRM-2. Mycologia 1977, 69, 164-172. [CrossRef]

120. Ayer, W.A.; Browne, L.M.; Lin, G. Metabolites of Leptographium wageneri, the causative agent of black stain root disease of conifers. J. Nat. Prod. 1989, 52, 119-129. [CrossRef] 
121. Borgschulte, K.; Rebuffat, S.; Trowitzsch-Kienast, W.; Schomburg, D.; Pinon, J.; Bodo, B. Isolation and structure elucidation of hymatoxins B-E and other phytotoxins from Hypoxylon mammatum fungal pathogen of leuce poplars. Tetrahedron 1991, 47, 8351-8360. [CrossRef]

122. Tabuchi, H.; Tajimi, A.; Ichihara, A. Phytotoxic metabolites isolated from Scolecotrichum graminis Fuckel. Biosci. Biotech. Biochem. 1994, 58, 1956-1959. [CrossRef]

123. Trisuwan, K.; Rukachaisirikul, V.; Sukpondma, Y.; Preedanon, S.; Phongpaichit, S.; Rungjindamai, N.; Sakayaroj, J. Epoxydons and a pyrone from the marine-derived fungus Nigrospora sp. PSU-F5. J. Nat. Prod. 2008, 71, 1323-1326. [CrossRef]

124. Arunpanichlert, J.; Rukachaisirikul, V.; Phongpaichit, S.; Supaphon, O.; Sakayaroj, J. Xylariphilone: A new azaphilone derivative from the seagrass-derived fungus Xylariales sp. PSU-ES163. Nat. Prod. Res. 2016, 30, 46-51. [CrossRef]

125. Fan, C.; Zhou, G.; Wang, W.; Zhang, G.; Zhu, T.; Che, Q.; Li, D. Tetralone derivatives from a deep-sea derived fungus Cladosporium sp. HDN17-58. Nat. Prod. Commun. 2021, 16. [CrossRef]

126. Sviridov, S.I. Secondary metabolites of Pyricularia oryzae. Chem. Nat. Compd. 1991, 27, 410-413. [CrossRef]

127. Zhang, Y.; Feng, Y.; Kramer, M.; Essmann, F.; Grond, S. A New Acetylenic compound and other bioactive metabolites from a shark gill-derived Penicillium strain. Rec. Nat. Prod. 2017, 11, 31-36.

128. Quang, T.H.; Huong, P.T.M.; Ngan, N.T.T.; Hanh, T.T.H.; Cuong, N.X.; Nam, N.H.; Minh, C.V. Secondary metabolites from a marine sponge-associated fungus Xenomyrothecium sp. IMBC-FP2.11. Vietnam J. Chem. 2020, 58, 752-758.

129. Iwasaki, S.; Muro, H.; Sasaki, K.; Nozoe, S.; Okuda, S.; Sato, Z. Isolations of phytotoxic substances produced by pyricularia oryzae cavara. Tetrahedron Lett. 1973, 14, 3537-3542. [CrossRef]

130. Krohn, K.; Biele, C.; Drogies, K.H.; Steingrover, K.; Aust, H.J.; Draeger, S.; Schulz, B. Fusidilactones, a new group of polycyclic lactones from an endophyte, Fusidium sp. Eur. J. Org. Chem. 2002, 14, 2331-2336. [CrossRef]

131. Yamaguchi, Y.; Masuma, R.; Kim, Y.-P.; Uchida, R.; Tomoda, H.; Omura, S. Taxonomy and secondary metabolites of Pseudobotrytis sp. FKA-25. Mycoscience 2004, 45, 9-16. [CrossRef]

132. Mancilla, G.; Jiménez-Teja, D.; Femenía-Rios, M.; Macías-Sánchez, A.J.; Collado, I.G.; Hernández-Galán, R. Novel macrolide from wild strains of the phytopathogen Fungus Colletotrichum acutatum. Nat. Prod. Commun. 2009, 4, 395-398. [CrossRef]

133. Ouchbani, T.; Zouihri, H.; Essassi, E.; Proksch, P.; Ng, S.W. (3R,4S)-3,4,8-Trihydroxy-1,2,3,4-tetrahydronaphthalen-1-one monohydrate from Embellisia eureka. Acta Cryst. 2012, E68, o1874. [CrossRef] [PubMed]

134. Venkatasubbaiah, P.; Chilton, W.S.J. Toxins produced by the Dogwood Anthracnose fungus Discula sp. J. Nat. Prod. 1991, 54, 1293-1297. [CrossRef]

135. Höller, U.; Konig, G.M.; Wright, A.D. Three new metabolites from marine-derived fungi of the genera coniothyrium and microsphaeropsis. J. Nat. Prod. 1999, 62, 114-118. [CrossRef] [PubMed]

136. Xie, F.; Chang, W.; Zhang, M.; Li, Y.; Li, W.; Shi, H.; Zheng, S.; Lou, H. Quinone derivatives isolated from the endolichenic fungus Phialocephala fortinii are Mdr1 modulators that combat azole resistance in Candida albicans. Sci. Rep. 2016, 6, 33687. [CrossRef] [PubMed]

137. De Souza, E.M.C.; Da Silva, E.L.; Marinho, A.M.R.; Marinho, P.S.B. (4S)-4,8-dihydroxy-1-tetralone and other chemical constituents from Pestalotiopsis sp. EJC07, endophytic from Bauhinia guianensis. An. Acad. Bras. Ciênc. 2016, 88, 29-33. [CrossRef]

138. Hsiao, Y.; Cheng, M.J.; Chang, H.S.; Wu, M.D.; Hsieh, S.Y.; Liu, T.W.; Lin, C.H.; Yuan, G.F.; Chen, I.S. Six new metabolites produced by Colletotrichum aotearoa 09F0161, an endophytic fungus isolated from Bredia oldhamii. Nat. Prod. Res. 2016, 30, 251-258. [CrossRef]

139. Kokubun, T.; Veitch, N.C.; Bridge, P.D.; Simmonds, M.S.J. Dihydroisocoumarins and a tetralone from Cytospora eucalypticola. Phytchemistry 2003, 62, 779-782. [CrossRef]

140. Gallo, M.B.C.; Cavalcanti, B.C.; Barros, F.W.; de Moraes, M.O.; Costa-Lotufo, L.V.; Pessoa, C.; Bastos, J.K.; Pupo, M.T. Chemical constituents of Papulaspora immersa, an endophyte from Smallanthus sonchifolius (Asteraceae), and their cytotoxic activity. Chem. Biodivers. 2010, 7, 2941-2950. [CrossRef]

141. Evidente, A.; Punzo, B.; Andolfi, A.; Cimmino, A.; Melck, D.; Luque, J. Lipophilic phytotoxins produced by Neofusicoccum parvum, a grapevine canker agent. Phytopathol. Mediterr. 2010, 49, 74-79.

142. El-Elimat, T.; Raja, H.A.; Figueroa, M.; Falkinham, J.O.; Oberlies, N.H. Isochromenones, isobenzofuranone, and tetrahydronaphthalenes produced by Paraphoma radicina, a fungus isolated from a freshwater habitat. Phytochemistry 2014, 104, 114-120. [CrossRef]

143. Sadorn, K.; Saepua, S.; Boonyuen, N.; Boonruangprapa, T.; Rachtawee, P.; Pittayakhajonwut, P. Antimicrobial activity and cytotoxicity of xanthoquinodin analogs from the fungus Cytospora eugeniae BCC42696. Phytochemistry 2018, 151, 99-109. [CrossRef]

144. Yang, H.X.; Peng, X.P.; Gao, H.; Zhang, H.M.; Wang, Z.R.; Li, G.; Lou, H.X. Pleosporalins H and I, two new heptaketides from the endophytic fungus Pleosporales sp. F46 by using OSMAC strategy. Nat. Prod. Res. 2021, 35, 13307-13313. [CrossRef] [PubMed]

145. Yang, X.-Y.; Zhang, J.-X.; Ding, Q.-Y.; He, Z.-C.; Zhu, C.-Y.; Zhang, K.-Q.; Niu, X.-M. Metabolites from two dominant thermophilic fungal species Thermomyces lanuginosus and Scytalidium thermophilum. Chem. Biodivers. 2020, 17, e2000137.

146. Sato, H.; Takishima, T.; Otomo, N.; Sakamura, S. Phytotoxins produced by the fungus of the larch shoot bligh. Nippon Nôgeikagaku Kaishi. 1982, 56, 649-653. [CrossRef]

147. Luo, G.; Chen, S.; Yu, J.; Yuan, J.; Zheng, L.; Liu, L.; Chen, B.; Li, J. Naphthalenones and naphthols isolated from the Saussurea laniceps endophytic fungus Didymella glomerata X223. Chem. Biodivers. 2020, 17, e2000315. [CrossRef] [PubMed] 
148. Bell, A.A.; Stipanovic, R.D.; Puhalla, J.E. Pentaketide metabolites of Verticillium dahliae: Identification of (+)-scytalone as a natural precursor to melanin. Tetrahedron 1976, 32, 1353-1356. [CrossRef]

149. Liu, Y.; Stuhldreier, F.; Kurtan, T.; Mandi, A.; Arumugam, S.; Lin, W.; Stork, B.; Wesselborg, S.; Weber, H.; Henrich, B.; et al. Daldinone derivatives from the mangrove-derived endophytic fungus Annulohypoxylon sp. RSC Adv. 2017, 7, 5381-5393. [CrossRef]

150. Zhang, J.; Liang, J.H.; Zhao, J.C.; Wang, Y.L.; Dong, P.P.; Liu, X.G.; Zhang, T.Y.; Wu, Y.Y.; Shang, D.J.; Zhang, Y.X.; et al. Xylarianins A-D from the endophytic fungus Xylaria sp. SYPF 8246 as natural inhibitors of human carboxylesterase 2. Bioorg. Chem. 2018, 81, 350-355. [CrossRef] [PubMed]

151. Padumadasa, C.; Xu, Y.M.; Wijeratne, E.M.K.; Espinosa-Artiles, P.; U’Ren, J.M.; Arnold, A.E.; Gunatilaka, A.A.L. Cytotoxic and noncytotoxic metabolites from Teratosphaeria sp. FL2137, a fungus associated with Pinus clausa. J. Nat. Prod. 2018, 81, 616-624. [CrossRef]

152. Bartman, C.D.; Campbell, I.M. Naphthalenone production in Aspergillus parvulus. Can. J. Microbiol. 1979, 25, 130-137. [CrossRef]

153. Hao, G.; Qing-Hua, Z.; Miao-Miao, J.; Jin-Shan, T.; Cheng-Du, M.; Kui, H.; Michio, N.; Nai-Li, W.; Xin-Sheng, Y. Polyketides from a marine sponge-derived fungus Mycelia sterilia and proton-proton long-range coupling. Magn. Reson. Chem. 2008, 46, 1148-1152. [CrossRef] [PubMed]

154. Rivera-Chávez, J.; El-Elimat, T.; Gallagher, J.M.; Graf, T.N.; Fournier, J.; Panigrahi, G.K.; Deep, G.; Bunch, R.L.; Raja, H.A.; Oberlies, N.H. Delitpyrones: $\alpha$-Pyrone derivatives from a freshwater Delitschia sp. Planta Med. 2019, 85, 62-71. [CrossRef]

155. Wu, Z.-C.; Li, D.-L.; Chen, Y.-C.; Zhang, W.-M. A new isofuranonaphthalenone and benzopyrans from the endophytic fungus Nodulisporium sp. A4 from Aquilaria sinensis. Helv. Chim. Acta 2010, 93, 920-924. [CrossRef]

156. Zhou, Y.H.; Zhang, M.; Zhu, R.X.; Zhang, J.Z.; Xie, F.; Li, X.B.; Chang, W.Q.; Wang, X.N.; Zhao, Z.T.; Lou, H.X. Heptaketides from an endolichenic fungus Biatriospora sp. and their antifungal activity. J. Nat. Prod. 2016, 79, 2149-2157. [CrossRef] [PubMed]

157. Ariefta, N.R.; Nikmawahda, H.T.; Koseki, T.; Shiono, Y. Fusopoltides B-E, new polyketides isolated from Fusarium solani B-18. Tetrahedron Lett. 2019, 60, 151361. [CrossRef]

158. Niu, S.; Tang, X.X.; Fan, Z.; Xia, J.M.; Xie, C.L.; Yang, X.W. Fusarisolins A-E, polyketides from the marine-derived fungus Fusarium solani H918. Mar. Drugs 2019, 17, 125. [CrossRef] [PubMed]

159. Itsuo, K.; Shunji, S.; Akihiko, M.; Akio, F. 5-Hydroxydihydrofusarubin, a Process for Its Preparation and Its Use as a Medicament. European Patent Application 0234431 A2, 2 September 1987.

160. Wen, Y.; Lv, Y.; Hao, J.; Chen, H.; Huang, Y.; Liu, C.; Huang, H.; Ma, Y.; Yang, X. Two new compounds of Penicillium polonicum, an endophytic fungus from Camptotheca acuminata Decne. Nat. Prod. Res. 2020, 34, 1879-1883. [CrossRef]

161. Stodůlková, E.; Man, P.; Kuzma, M.; Černý, J.; Císařová, I.; Kubátová, A.; Chudíčková, M.; Kolařík, M.; Flieger, M. A highly diverse spectrum of naphthoquinone derivatives produced by the endophytic fungus Biatriospora sp. CCF 4378. Folia Microbiol. (Praha) 2015, 60, 259-267. [CrossRef]

162. Sakagami, Y.; Sano, A.; Marumo, S.; Yoshikawa, N.; Nakagawa, J. Cladosporol, a plant growth regurator produced by fungus Cladosporium cladosporioides. Symp. Chem. Nat. Prod. 1992, 134-141. [CrossRef]

163. Sakagami, Y.; Sano, A.; Hara, O.; Mikawa, T.; Marumo, S. Cladosporol, $\beta$-1,3-glucan biosynthesis inhibitor, isolated from fungus, Cladosporium cladosporioides. Tetrahedron Lett. 1995, 36, 1469-1472. [CrossRef]

164. Zurlo, D.; Ziccardi, P.; Votino, C.; Colangelo, T.; Cerchia, C.; Dal Piaz, F.; Dallavalle, S.; Moricca, S.; Novellino, E.; Lavecchia, A.; et al. The antiproliferative and proapoptotic effects of cladosporols A and B are related to their different binding mode as PPAR $\gamma$ ligands. Biochem. Pharmacol. 2016, 108, 22-35. [CrossRef] [PubMed]

165. Nasini, G.; Arnone, A.; Assante, G.; Bava, A.; Moricca, S.; Ragazzi, A. Secondary mould metabolites of Cladosporium tenuissimum, a hyperparasite of rust fungi. Phytochemistry 2004, 65, 2107-2111. [CrossRef] [PubMed]

166. Yamazaki, H.; Yagi, A.; Akaishi, M.; Kirikoshi, R.; Takahashi, O.; Abe, T.; Chiba, S.; Takahashi, K.; Iwakura, N.; Namikoshi, M.; et al. Halogenated cladosporols produced by the sodium halide-supplemented fermentation of the plant-associated fungus Cladosporium sp. TMPU1621. Tetrahedron Lett. 2018, 59, 1913-1915. [CrossRef]

167. Fan, Z.; Sun, Z.; Chen, Y.; Li, H.; Zhang, W. Cladosperanol A, a new dimeric tetralone from marine-derived fungus cladosporium perangustum FS62. Nat. Prod. Res. Dev. 2016, 28, 486-489. 